\title{
FOTOGRAFÍA Y REPRESENTACIÓN DE LA ESCUELA PRIVADA MADRILEÑA EN EL FRANQUISMO. ENTRE LA PROPAGANDA Y EL RELATO*
}

\section{Photography and representation of the private school during the Francoism in Madrid. Between advertising and story}

\author{
Sara Ramos Zamora, ${ }^{\oplus}$ Teresa Rabazas Romero ${ }^{\varphi}$ \\ y Carmen Colmenar Orzaes ${ }^{\pi}$
}

Fecha de recepción: 27/07/2017 • Fecha de aceptación: 06/10/2017

Resumen. El uso de las fotografías como fuentes para la Historia de la Educación forma parte de una de las tendencias de la historiografía contemporánea que ha adquirido un mayor protagonismo en la actualidad. Este artículo se va a centrar en el valor de las imágenes como fuente histórica para conocer algunos elementos representativos de algunos centros escolares privados madrileños durante el periodo franquista. El análisis de la investigación ha girado en torno a las representaciones más características de estos centros, destacando los espacios, la religiosidad, la enseñanza y las actividades como elementos de identidad y distinción: museos, exposiciones escolares, deportes, asociaciones y actividades artísticas. La principal fuente de documentación ha sido el archivo fotográfico perteneciente a la colección de memorias de prácticas conservadas en el Fondo Anselmo Romero Marín del Museo de Historia de la Educación «Manuel Bartolomé Cossío» de la Universidad Complutense.

Palabras clave: Imágenes; Colegios católicos; Franquismo; Memorias de prácticas; Madrid

\footnotetext{
* El presente trabajo se inscribe en el marco del proyecto de investigación titulado «La fotografía escolar en colecciones documentales de ámbito estatal (1900-1970)». Proyecto financiado por el Ministerio de Economía y Competitividad, número de referencia: EDU-2014-52498-C2-1-P

${ }^{\oplus}$ Departamento de Estudios Educativos, Facultad de Educación, Universidad Complutense de Madrid. C. Rector Royo Villanova, s/n, 28040 Madrid, España. sramosz@ucm.es

${ }^{\varphi}$ Departamento de Estudios Educativos, Facultad de Educación, Universidad Complutense de Madrid. C. Rector Royo Villanova, s/n, 28040 Madrid, España. rabarom@ucm.es

${ }^{\pi}$ Departamento de Estudios Educativos, Facultad de Educación, Universidad Complutense de Madrid. C. Rector Royo Villanova, s/n, 28040 Madrid, España. mcolmen@ucm.es
}

Cómo citar este artículo: Ramos Zamora, Sara; Teresa Rabazas Romero y Carmen Colmenar Orzaes. «Fotografía y representación de la escuela privada madrileña en el franquismo. Entre la propaganda y el relato». Historia y Memoria de la Educación 8 (2018): 397-448. 
Abstract. The use of photographs as sources for the History of Education is one of the new topics of contemporary historiography that is assuming a greater role today. This paper will focus on the value of images as a historical source for the purpose of studying certain representative elements of some private schools Madrid during Franco's regime. The research revolves around the most characteristic representations of these schools, highlighting the spaces, religiousness, education and activities as elements of identity and distinction: museums, school exhibitions, sports, associations and artistic activities. The main sources of documentation used come from the photographic archive in the collection of teacher-training reports preserved in the fund Anselmo Romero Marin in the Museum of History of Education "Manuel Bartolome Cossio» of the Complutense University.

Keywords: Images; Catholics schools; Francoism; Practices reports; Madrid

\section{INTRODUCCIÓN}

Desde hace más de una década, el interés creciente por el uso de las fuentes iconográficas en la historiografía educativa ha sido una tendencia desarrollada por muchos historiadores de la educación. En la década de los años ochenta, la revista Histoire de l'Education (1986) publicaba una sección monográfica sobre "Images et education» en su número 30. Años más tarde, se celebraba en Bélgica el International Standing Conference for the History of Education (ISCHE) (1998) dedicado a la cultura visual bajo el título "The Challenge of the Visual in the History of Education». A comienzos del siglo XXI, las revistas Paedagogica Historica (2000) y History of Education (2001) también destinan un número monográfico a los avances producidos en esta nueva metodología historiográfica, no exenta de reflexiones críticas acerca de las limitaciones de esta fuente. ${ }^{1}$ Fruto de este debate internacional, en el contexto español se publica un artículo en el año 2006 en la revista de Historia de la Educación, que será pionero y donde se invita a reflexionar sobre las posibilidades de las imágenes en la representación de las prácticas escolares. ${ }^{2}$ Asimismo, el Grup d'Estudis d'Història de l'Educació de la Universidad de las Islas Baleares como resultado de diversas investigaciones genera varias publicaciones

\footnotetext{
${ }^{1}$ El trabajo de Marc Depaepe y Bregt Henkens es un claro ejemplo: Marc Depape y Bregt Henkens, «The Challenge of the Visual in the History of Education», Paedagogica Historica. International Journal of the History of Education 36, no.1 (2000): 11-17.

${ }^{2}$ M. ${ }^{a}$ del Mar del Pozo Andrés, «Imágenes e historia de la educación: construcción, reconstrucción y representación de las prácticas escolares en el aula». Historia de la Educación 25 (2006): 291-315.
} 
importantes ${ }^{3}$ entre las que destaca el número monográfico publicado en Educació i História (2010). La actividad investigadora de este grupo en relación a esta fuente historiográfica se amplía en estos últimos años en colaboración con las Universidades de Alcalá de Henares y la Complutense de Madrid, trabajando conjuntamente en el número monográfico de la revista Encounters on Education (2016) dedicado a «Photography and School Cultures».

Hasta ahora las investigaciones que se han realizado sobre el análisis iconográfico han girado en torno a diferentes enfoques y consideraciones sobre la fotografía como fuente histórica, y como elemento evocador para la memoria colectiva. Gran parte de los trabajos se han orientado al ámbito de la enseñanza pública, rural y urbana, pero nuestro interés se va a centrar en el valor de las imágenes como fuente histórica para conocer algunos elementos de distinción de los centros escolares privados madrileños durante el periodo franquista, que constituyeron los principales discursos propagandísticos que emplearon como instrumento de difusión y reclamo publicitario. Por otro lado, nos ha interesado visualizar algunos aspectos de su práctica docente. El análisis de la investigación se centrará, por tanto, en dos planos diferenciados: en primer lugar, se estudian las representaciones del marketing escolar más características de estos centros, a través de los edificios, la religiosidad y las actividades como elementos de identidad y distinción (museos, laboratorios, exposiciones escolares, actividades deportivas, artísticas, asociaciones, etc.); en segundo lugar, se analizarán las imágenes que representan la enseñanza en el aula como un elemento relevante y significativo de su identidad como docentes en centros privados (metodología competitiva y personalizada).

\footnotetext{
${ }^{3}$ Destacamos algunos trabajos: Francesca Comas Rubí, Xavier Motilla Salas y Bernat Sureda García, Fotografia e història de l'educació. Iconografia de la modernització educativa (Palma: Leonard Muntaner, 2012); Francesa Comas Rubi, «Localització, anàlisi i utilització de la fotografía com a font per a la historia de lèducació els projectes desenvolupats en el Grup d'Estudis d'Història de l'Educació de la UIB», en Investigar la Història de l'Educació am imatges, coord. Eulàlia Collelldemont (Vic: Eumogràfic - MUVIP, 2014), 53-64; Francesca Comas Rubí, Sara González Gómez, Xavier Motilla Salas y Bernat Sureda García, Imatges de l'escola, imatge de l'educació (Palma: Universidad de las Islas Balears, 2014). Actas de les Xxi Jornades d'Història de l'Educació, celebradas entre el 26 al 28 de noviembre de 2014; Gabriel Barceló Bauzá, Francesca Comas Rubí y Bernat Sureda García, «Abriendo la caja negra: la escuela pública española de postguerra», Revista de Educación 371 (2015): 61-82.
} 


\section{LA ESCUELA PRIVADA RELIGIOSA EN MADRID: MARIANISTAS, LASALIANOS Y TERESIANAS}

La enseñanza privada religiosa en España ha sido objeto de interés, en su mayoría, por investigadores e investigadoras pertenecientes a las órdenes y congregaciones religiosas, como ya ha puesto de manifiesto el profesor Paulí Dávila en un trabajo reciente en el que se destacan como aportaciones relevantes los estudios de Revuelta, Faubell, Valle y Bartolomé, entre otros. ${ }^{4}$ La historia de la acción educadora de la Iglesia y de las órdenes, congregaciones e institutos religiosos católicos ha sido reconstruida por autores relevantes en el ámbito de la Historia de la Educación. ${ }^{5}$ La consulta de las investigaciones realizadas por autores como Delaunay, Dávila, Faubell, Flecha, Fullana, Galino, Gutiérrez, González y de Isasa, Ostolaza, Rosique, Valle, Yetano, Dávila, Naya y Murua o Dávila y Naya dan cuenta de ello. También las obras publicadas con carácter conmemorativo por las propias instituciones educativas religiosas han sido un material excelente que además conecta directamente con la imagen

\footnotetext{
${ }^{4}$ Paulí Dávila Balsera, «Las órdenes y congregaciones religiosas francesas y su impacto sobre la educación en España. Siglos XIX y XX», en Francia en la educación de la España Contemporánea (1808-2008), ed. José María Hernández Díaz (Salamanca: Ediciones Universidad Salamanca, 2011), 101-159, cfr. p. 103.

${ }^{5}$ Paulí Dávila Balsera, Luis María Naya Garmendia e Hilario Murua Cartón, Bajo el signo de la educación. 100 años de la Salle en Gipuzkoa (Bilbao: Hermanos de las Escuelas Cristianas, 2009); Paulí Dávila y Luis M. Naya, «La enseñanza privada religiosa en España: instituciones, políticas e identidades», en Laicidade, Religioes e Educaçao na Europa do Sul no Século XX, ed. Joaquím Pintassilgo (Lisboa: Instituto de Eduaçao da Universidade de Lisboa, 2013), 367-392; Paulí Dávila, Luis María Naya e Hilario Murua, «Prácticas y actividades religiosas en los colegios privados del País Vasco durante el siglo xx», Historia y Memoria de la Educación 4 (2016): 141-175; Jean Marie Delaunay, «Exilio o refugio en España (veinticinco años después)», Anuario de la Iglesia 16 (2005): 153-164; Vicente Faubell Zapata, «Órdenes, Congregaciones y Asociaciones eclesiales masculinas dedicadas a la educación y a la enseñanza», en Historia de la acción educadora de la Iglesia en España. Tomo II. Edad Contemporánea, ed. Bernabé Bartolomé (Madrid: Biblioteca de Autores Cristianos, 1997), 323-448, y «Educación y órdenes y congregaciones religiosas en la España del siglo xx», Revista de Educación 2000 (Número Extraordinario): 137-200; Irene Gutiérrez Ruiz, «El maestro de la experiencia Somosaguas», Tendencias pedagógicas 14 (2009): 181-189, y Experiencia Somosaguas (Madrid: Iter ediciones, 1970); Maitane Ostolaza Esnal, Entre religión y modernidad: los colegios de las Congregaciones Religiosas en la construcción de la sociedad guipuzcoana contemporánea, 1876-1931 (Bilbao: Universidad del País Vasco, 2000); Maitane Ostolaza y Pere Fullana, «Escuela católica y modernización. Las nuevas congregaciones religiosas (1900-1930)», en La secularización conflictiva. España (1898-1931), eds. Julio de la Cueva y Feliciano Montero (Madrid: Biblioteca Nueva, 2007), 187-213; Francisca Rosique Navarro, Historia de la Institución Teresiana (1911-1936) (Madrid: Silex Ediciones, 2014); Ángela del Valle López, «Una pedagogía para la educación integral en la obra de Pedro Poveda: Desarrollo de las capacidades y actitudes físicas», Historia de la Educación 14-15 (1995-1996), 173-196 y Ana Yetano, La enseñanza religiosa en la España de la Restauración (1900-1920). (Barcelona: Anthropos, 1987).
} 
que los propios centros educativos religiosos han querido transmitir a modo de marketing educativo. ${ }^{6}$ Cuando empleamos el término marketing nos estamos refiriendo - $-\mathrm{y}$ con esa acepción lo emplearemos a lo largo de este trabajo - a la tarea intencionada de visibilizar una imagen determinada del centro educativo con fines publicitarios, tratando de hacer atractiva su oferta a las familias potencialmente susceptibles de confiar la educación de sus hijos a esas instituciones, con el objetivo de personalizar un servicio que imprime un carácter propio, y que incrementa la participación de los agentes sociales implicados consolidando relaciones más a largo plazo.

En estos trabajos se constata que a lo largo del siglo xx la formación de los hijos de clase acomodada en España estuvo, en gran parte, en manos de las órdenes y congregaciones religiosas, teniendo un avance espectacular en el periodo franquista. El apoyo de la Iglesia al régimen de Franco a través de una legislación que volvía a establecer la Compañía de Jesús en el año 1938, derogaba en 1939 la Ley de Confesiones y Congregaciones Religiosas de 1933, y establecía una legislación educativa favorable a la educación religiosa, permitieron que las instituciones religiosas dedicadas a la enseñanza como los escolapias/os, padres marianistas, maristas, Hermanos de las Escuelas cristianas-La Salle, salesianos/as, ursulinas, jesuitas, jesuitinas, agustinos, etc. e institutos como la Institución Teresiana y el Opus Dei, fueran creando escuelas en todos los niveles educativos. No nos vamos a detener en reconstruir la historia de estas instituciones, puesto que ya lo han hecho varios autores especialistas en esta línea de investigación, como se ha referenciado más arriba, pero en relación a las congregaciones religiosas, hay un hecho que queremos destacar sobre su llegada a España, al producirse como consecuencia de la política laicista francesa de finales del siglo xIX y comienzos del siglo xx. Esta situación provocó la expulsión de las congregaciones religiosas de-

\footnotetext{
${ }^{6}$ Del Colegio Nuestra Señora de las Maravillas, se ha consultado: Antonio Calvo, El Colegio de Nuestra Señora de las Maravillas. Crónica de cien años. 1892-1992 (Madrid: Hermanos La Salle: 1995); Hermanos La Salle, Cien años maravillosos. Colegio Nuestra Señora de las Maravillas. La Salle. 18921992 (Madrid: Hermanos La Salle, 1994). Sobre el Colegio Nuestra Señora del Pilar, se han tenido en cuenta varias publicaciones, entre las que destacamos: Asociación de Antiguos Alumnos del Colegio del Pilar, Colegio Nuestra Señora del Pilar, 1946. Recuerdos en el año de las Bodas de oro de la compañía de María en España (Madrid, 1946), Bodas de Oro del Colegio Nuestra Señora del Pilar (Madrid: 1957), y 100 años. El Pilar. La enseñanza nos hará libres (Madrid: 2007); AA. VV., El Pilar, cien años de historia, 1907-2007 (Madrid: Colegio Nuestra Señora del Pilar, 2007); y Juan de Isasa González de Ubieta, Colegio del Pilar. 75 años (1907-1982). Abiertos a la sociedad (Madrid: Colegio el Pilar, 1982).
} 
dicadas a la educación en Francia, siendo España uno de los países de acogida de muchas de estas instituciones. ${ }^{7}$

En el contexto urbano madrileño, podemos destacar, como ejemplos representativos, los colegios de ciertas congregaciones religiosas que se dirigieron a formar a los hijos e hijas de las clases altas y burguesas, como El Pilar (padres marianistas), San José (maristas), Nuestra Señora de la Escuelas Pías (escolapias), Real Colegio de las Escuelas Pías de San Fernando (escolapios), Instituto Véritas (teresianas), Nuestra Señora del Buen Consejo (agustinos) y el Colegio Maravillas-El Viso (hermanos de las escuelas cristianas-La Salle), entre otros. Dadas las limitaciones y la naturaleza de nuestras fuentes, se han seleccionado los colegios que aportan una mayor calidad de las fotografías posiblemente con una finalidad publicitaria o propagandística, en donde las imágenes son utilizadas como elementos de identidad y distinción, lo que llevaba a una inevitable selección de la clase social a la que iban dirigidas.

Los Padres Marianistas y los Hermanos de las Escuelas Cristianas-La Salle fueron dos de las más destacadas comunidades religiosas que se asentaron en España. Por otra parte, nos ha parecido interesante seleccionar uno de los centros destinados a la formación de las mujeres de clase media alta, creado por la Institución Teresiana (en adelante IT). Inspirada en la obra del Padre Pedro Poveda, es una organización seglar creada en España en 1914, con unos orígenes diferentes a las congregaciones religiosas procedentes de otros países, tal y como manifiesta Francisca Rosique en la obra que recoge la historia de la IT durante el primer tercio del siglo xx: «La Institución había nacido para hacer precisamente lo que no podían hacer las congregaciones religiosas ${ }^{8}$

A partir de estas premisas, el análisis se ha centrado en cuatro centros: dos de ellos pertenecientes a los Padres marianistas (Colegio Nuestra Señora del Pilar y Colegio Santa María del Pilar), uno a los Hermanos de las Escuelas Cristianas-La Salle (Maravillas-El Viso) y otro, por últi-

\footnotetext{
${ }^{7}$ Faubell Zapata, «Educación y órdenes y Congregaciones religiosas en la España del siglo xx», 142.

${ }^{8}$ Rosique Navarro, Historia de la Institución Teresiana (1911-1936), 34. La Institución Teresiana se dirige fundamentalmente a la educación de la mujer y a la formación del profesorado, pero desde una perspectiva diferente. Pedro Poveda en sus inicios se interesó por crear institutos religiosos que formasen a las mujeres para desempeñar puestos docentes en la enseñanza oficial.
} 
mo, un colegio privado dirigido a la educación de la mujer creado por la Institución Teresiana (Instituto Véritas).

\section{CUESTIONES METODOLÓGICAS Y FUENTES DE ESTUDIO}

Para este trabajo se han utilizado las fotografías insertas en las memorias de prácticas de Pedagogía conservadas en el Museo de Historia de la Educación «Manuel Bartolomé Cossío» de la Facultad de Educación de la Universidad Complutense de Madrid (UCM), elaboradas por los estudiantes en los años cincuenta y sesenta del siglo pasado para la asignatura que impartía el profesor Anselmo Romero Marín, catedrático de Pedagogía General y Racional desde 1949. Como se ha puesto de relieve en trabajos anteriores, ${ }^{9}$ estas memorias de prácticas constituyen una valiosa fuente para reconstruir diferentes aspectos de la cultura escolar en España en la etapa del franquismo. Dichas prácticas consistían «en la observación sistematizada y el análisis crítico de una determinada situación escolar», ${ }^{10}$ ya fuese un tema o problema pedagógico o bien una institución educativa concreta. La mayoría de las memorias examinadas adjuntan una serie de imágenes (fotografías, gráficos, planos, etc.) que constituyen una riqueza indudable para la reconstrucción de la cultura escolar de la España franquista. Como señalan María del Mar del Pozo y Teresa Rabazas, es muy probable que el profesor de Prácticas de Pedagogía insistiera en la necesidad de que los trabajos recogieran imágenes y fotografías, que ilustraran y corroboraran lo que se escribía en el texto, ya que la mayoría de las memorias incluían elementos visuales, aunque el tratamiento que se les daba difería entre los distintos alumnos. ${ }^{11}$

\footnotetext{
${ }^{9}$ Anastasio Martínez Navarro, «Un Seminario sobre fuentes históricas en el Museo de historia de la Educación de la Facultad de Educación de la Universidad Complutense», Revista Complutense de Educación 8, no. 1 (1997): 305-318; Carmen Colmenar Orzaes, «El Museo de historia de la Educación Manuel Bartolomé Cossío», en El patrimonio histórico-educativo. Su conservación y estudio, ed. Julio Ruiz Berrio (Madrid: Biblioteca Nueva, 2010), 339-361; María del Mar del Pozo Andrés y Teresa Rabazas Romero, «Imatges fotogràfiques i cultura escolar en el franquisme: una exploració de l'arxiu etnogràfic», Educació i Història. Revista d'Història de l'Educació 15 (2010): 165-194. Se pueden consultar también los trabajos publicados por Carmen Colmenar, María Poveda, Javier Pericacho, Teresa Rabazas y Sara Ramos en Patrimonio y etnografía de la escuela en España y Portugal durante el siglo XX, eds. Pedro Luís Moreno Martínez y Ana Sebastián Vicente (Murcia: SEPHE y CEME: 2012).

${ }^{10}$ Martínez Navarro, «Un Seminario sobre fuentes históricas en el Museo», 306.

${ }^{11}$ Del Pozo y Rabazas, «Imatges fotogràfiques i cultura escolar en el franquisme», 178.
} 
El uso que los estudiantes de pedagogía realizaron de las imágenes en las memorias reflejan una "imagen de progreso» ${ }^{12}$ a partir de unas fotografías de gran calidad realizadas por fotógrafos profesionales posiblemente con fines propagandísticos. Aunque también incluyen imágenes realizadas por ellos mismos, proporcionando informaciones relevantes sobre la realidad escolar que quieren destacar como profesores.

No quisiéramos pasar por alto la crítica externa de las fuentes iconográficas que contiene el archivo fotográfico configurado por las memorias de prácticas que realizaron los estudiantes de Pedagogía en la UCM durante las décadas de los años cincuenta, sesenta y setenta. El origen del «archivo visual», como señala Ian Grosvenor ${ }^{13}$ está condicionado por el contexto de cómo ha sido configurado dicho fondo, la intencionalidad del fotógrafo y las informaciones que se consigan obtener.

Una de las características de este fondo es que muchas fotografías insertas en las memorias están muy alejadas del contexto en el que fueron producidas. Con estas fotografías los estudiantes querían mostrar la cultura escolar de los centros donde estaban realizando sus prácticas, finalidad bien distinta a la de muchas de las fotografías que emplearon, ya que procedían de las memorias escolares oficiales que los centros publicitaron para difundir una imagen determinada más próxima a una estrategia de marketing comercial. Por tanto, algunos autores de las memorias utilizaron esas fotos institucionales, mediatizando así su función y transformándola en un relato que ellos mismos querían construir, representando los avances e innovaciones de los colegios privados. Estas fotografías se fueron intercalando con las que los autores de las memorias realizaron como amateurs, así como con algunas de las empleadas por los propios centros docentes para celebrar actos conmemorativos o insertas en memorias institucionales con fines divulgativos o publicitarios.

Las imágenes que aparecen en las memorias se pueden incluir en dos tipos de fuentes iconográficas: fotografías publicadas (tarjetas postales, recortes fotográficos procedentes de las memorias o anuarios de los cen-

\footnotetext{
${ }^{12}$ Catherine Burke e Ian Grosvenor, «The progressive image in the history of education: stories of two schools», Visual Studies 22, no. 2 (2007): 157-158.

${ }^{13}$ Ian Grosvenor, «From the "Eye of History" to "a Second Gaze": The Visual Archive and the Marginalized in the History of Education», History of Education 36, no. 4-5 (2007): 613.
} 
tros escolares,...), que fueron encargadas a fotógrafos profesionales con una clara función publicitaria, y fotografías no publicadas que realizaron los autores y autoras de las memorias como amateurs, que representan la realidad escolar desde su punto de vista o perspectiva personal, seleccionando los aspectos educativos más relevantes. La finalidad de las fotografías, por tanto, determinarán dos tipos de discursos en el análisis iconográfico, que se irán intercalando a lo largo de los trabajos. Ambas dimensiones, la institucional y la personal, se van intercalando en los trabajos, configurando un análisis muy diverso y de gran riqueza sobre algunos de los elementos más representativos de la enseñanza privada madrileña.

En relación a las fotografías publicadas, y especialmente aquellas en formato tarjeta postal, Viñao y Martínez señalan que las tarjetas postales se convirtieron en un elemento que conformó la imagen individual y social de la institución. Como si se tratara de una tarjeta o carta de presentación en la sociedad, tal y como lo expresan en el siguiente texto:

Picture postcards thus became an element that made up the individual and social image-memory of the institution to which they referred. They acted as a visiting card and a presentation in society. They showed how the institution wished to be seen, visualized and remembered socially. The edition of booklets and wallets with a specific number of postcards, or loose postcards, presupposed a specific desire to influence and condition the social image-memory of the institution. Likewise, the selection of the images reflected a specific conception to be presented to society. ${ }^{14}$

También dentro de este primer grupo de fotografías, las imágenes recortadas procedentes de las memorias de los centros o de libros conmemorativos que la propia institución elabora, incluidas por los autores/as de estos trabajos, constituyen un medio publicitario que se define por los intereses de las escuelas objeto de estudio. A pesar de las

\footnotetext{
${ }^{14}$ Antonio Viñao y María José Martínez, «Picture Postcards as a Tool for Constructing and Reconstructing Educational Memory (Spain, 19th-20th Centuries)», en School Memories New Trends in the History of Education, eds. Cristina Yanes-Cabrera, Juri Meda y Antonio Viñao (Suiza: Springer, 2017), 35.
} 
limitaciones que señalan Dávila y Naya con este tipo de fuentes, ${ }^{15}$ nos permiten escribir una historia de la imagen que estas escuelas pretendían transmitir al público, con el fin de comprender las mediaciones y el universo simbólico que se dieron en ciertas escuelas privadas para transmitir los valores sociales, culturales, económicos, elitistas, etc. que seguramente fueron requeridos por los padres que enviaron a sus hijos a estos colegios. ${ }^{16}$

El grupo de fotografías no publicadas de las memorias seleccionadas constituye una fuente de gran valor historiográfico, como se ha puesto de manifiesto en los trabajos que hemos publicado recientemente. Una de las razones señaladas es que la mayor parte de los autores y autoras son profesores/as de los centros donde realizan las prácticas. Las fotografías que emplearon no son de fotógrafos profesionales, sino amateurs, la mayoría fueron realizadas por los autores/as de los trabajos. Lo cierto es que estas fotografías recrean una construcción social de lo que los maestros/ as consideran lo esencial de su práctica educativa. Una de las autoras reconoce la importancia de conocer la institución desde dentro:

Cuando se visita o se conoce una obra desde fuera, con una visión externa y ajena, aunque se ponga un gran empeño y afán para conocerla, es difícil quedarse con la imagen auténtica de lo que aquello es. Ahora bien, cuando esta obra se conoce desde dentro, a diario, y en pleno y continuo contacto con las demás profesoras y las alumnas, es lógico suponer que el conocimiento se acerca bastante a la realidad. ${ }^{17}$

Por otra parte, estas fotografías fueron elaboradas con un claro propósito informativo, proporcionando un registro etnográfico extraordinario, dejando entrever aspectos que formaban parte del colectivo, de su

\footnotetext{
${ }^{15}$ Paulí Dávila, Luis M. ${ }^{2}$ Naya e Iñaki Zabaleta, «Internados religiosos: marketing del espacio a través de las Memorias escolares en España durante el primer tercio del siglo xx», en Espacios y patrimonio histórico-educativo. VII Jornadas científicas de la SEPHE y V Simposio Iberoamericano, coords. Paulí Dávila y Luis M. ${ }^{2}$ Naya (Donostia-San Sebastián: Universidad del País Vasco, 2016), 191.

${ }^{16}$ Paulí Dávila, Luis María Naya e Iñaki Zabaleta, «Memory and Yearbooks: An Analysis of Their Structure and Evolution in Religious Schools in 20th Century Spain», en School Memories New Trends in the History of Education, 67.

${ }^{17}$ María Jesús Irene Maestro García, Estudio general sobre el Instituto Véritas y su enseñanza individualizada en los cursos: párvulos, $1^{\circ}, 2^{\circ}$ y $3^{\circ}$ de primaria (Fondo Romero Marín 852: 1966), 5. En adelante se citará de forma abreviada FRM.
} 
identidad, de sus prácticas simbólicas e incluso de aspectos del pensamiento de los profesores a los que difícilmente se puede acceder con otro tipo de fuentes.

La metodología de nuestro trabajo se ha visto enriquecida por la triangulación de las fuentes, lo que nos ha permitido acudir a testimonios orales ${ }^{18}$ (autores/as de las memorias, profesorado y ex-directores/as de los centros, ex-alumnos/as, etc.); también se han consultado algunos documentos de archivo de los colegios, memorias escolares, fotografías publicadas en anuarios, revistas escolares, folletos informativos y divulgativos, etc. Todas estas fuentes han contribuido a realizar una primera aproximación hacia los diferentes discursos que difundieron algunos centros privados en Madrid, así como la visualización de ciertas metodologías docentes que se pusieron en práctica durante el franquismo.

Para llevar a cabo el estudio de las representaciones de las escuelas privadas madrileñas a través de las imágenes fotográficas insertas en las memorias de prácticas, nos hemos basado en la técnica del análisis categorial. ${ }^{19}$ Este enfoque metodológico nos ha permitido categorizar cuatro unidades de significación que han sido seleccionadas por el nivel de representación y especificidad de los centros privados, así como por el tipo de discurso que se desprende del análisis iconográfico. En un primer nivel se han seleccionado tres categorías que constituyen elementos diferenciadores de estos centros y que les dotan de identidad propia. Una primera categoría se centra en la configuración de los espacios e instalaciones en la que se incluyen aquellas fotografías dedicadas a los edificios de los centros, así como las instalaciones del mismo en las que no aparece representada ninguna actividad escolar. Una segunda categoría, dedicada a la representación de la religiosidad, incluye aquellas imágenes en las que aparecen actos religiosos del interior o exterior de las iglesias o capillas de los colegios. Una tercera categoría agrupa fotografías dedicadas a actividades que resultan ser un elemento diferenciador de otros centros escolares y que constituyen una parte fundamental del

\footnotetext{
${ }^{18}$ La riqueza de los testimonios orales de los autores y autoras de las memorias nos han aportado una información muy valiosa sobre la intencionalidad de ciertas fotografías para su posterior análisis, así como de la tipología utilizada.

${ }^{19}$ Laurence Bardin, Análisis de contenido (Madrid: Akal, 2002); Elisa Belloti, «Qualitative Methods and Visualizations in the Study of Friendship Networks», Sociological Research Online 21, no. 2 (2016): 2. [http://www.socresonline.org.uk/21/2/2.html].
} 
proyecto educativo. Se incluyen fotografías sobre museos, laboratorios de ciencias, las actividades deportivas, artísticas (coro, teatro, rondallas, etc.) y extraescolares, así como las asociaciones de antiguos alumnos. Se ha elegido una cuarta y última categoría que contiene fotografías que representan acciones escolares de la vida cotidiana del aula, a partir de las cuales tratamos de analizar los diferentes modelos de enseñanza desarrollados en estos centros. No obstante, somos conscientes de la dificultad de clasificar algunas imágenes que podrían estar representadas en más de una de las categorías establecidas.

De las cuarenta y dos memorias de prácticas que hacen referencia a los centros privados madrileños que contiene el Fondo Romero Marín, seleccionamos un total de nueve memorias correspondientes a los cuatro centros educativos objeto de este estudio. En total hemos analizado 228 fotografías, de las cuales 59 corresponden a la primera categoría dedicada a edificios e instalaciones, 35 a la representación de la religiosidad, 83 a las actividades como elemento diferenciador del proyecto educativo de estos centros, y 51 a la enseñanza en el aula.

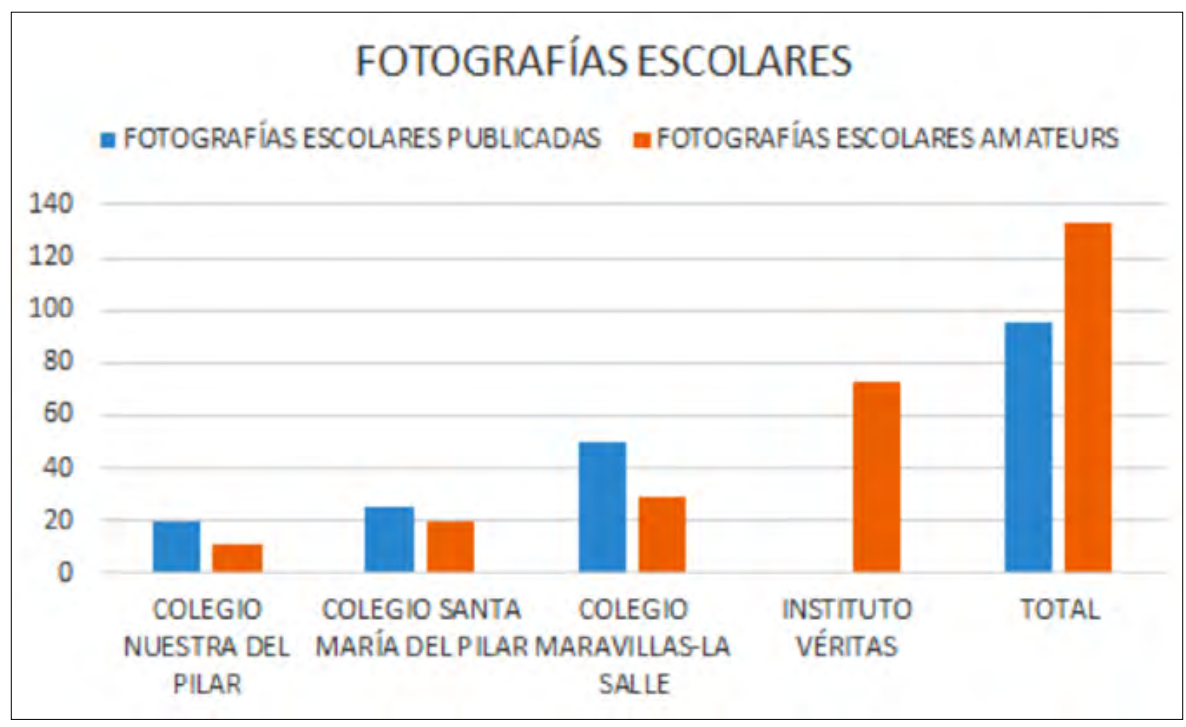

Fuente: Elaboración Propia.

Si atendemos al contexto de producción de las imágenes, del conjunto de fotografías consultadas, el $41.6 \%$ se corresponden con fotogra- 
fías profesionales o proceden de las memorias escolares. Se trata de las fotografías que hacen referencia a la excelencia de las instalaciones y edificios, así como a las señas de identidad corporativa de los colegios: la religiosidad y las diversas actividades complementarias que se ofertan. El otro 58.4\% constituye el grupo de fotografías realizadas por los autores/as de las memorias como amateurs. La mayor parte de estas imágenes representan la dimensión personal del docente. A través de estas fuentes iconográficas los profesores/as reconstruyen un relato de su práctica educativa, destacando lo que les identifica como docentes de un colegio privado.

\section{REPRESENTACIÓN DEL MARKETING ESCOLAR EN LOS COLEGIOS PRIVADOS DE MADRID: ESPACIOS, RELIGIOSIDAD Y ACTIVIDADES}

\section{La representación de los espacios. Dos modelos arquitectónicos:} neogótico y arquitectura moderna

Los edificios escolares constituyen un elemento determinante para representar un determinado orden social y resultan ser un excelente reclamo publicitario. En este sentido, consideramos que el elevado número de fotografías que visibilizan el emplazamiento y las instalaciones de estas escuelas las convierte en la mejor carta de presentación social. Las imágenes significan y connotan, y además, forman parte de un sistema de ideas destinado a hacer propaganda de un determinado orden social. ${ }^{20}$ La mayoría de los colegios privados estudiados resaltan la arquitectura del centro como un lugar emblemático, con identidad propia. Tal y como constata el profesor Honorio Velasco, en la etnografía escolar han tenido un mayor protagonismo las imágenes de las personas, pero no por ello tienen menor entidad las instituciones «a menudo cristalizada en presentaciones de los edificios que ocupaban, convertidos estos en emblemas. A ambos contenidos se les debe haber otorgado la importancia debida». ${ }^{21}$

\footnotetext{
${ }^{20}$ Anne McCauley, «Francois Arago and the politics of the French Invention of Photography», en Multiple views: logan grant essays on photography. 1983-1989, ed. Daniel P. Jounger (Alburquerque: University of New Mexico Press, 1991), 43-69.

${ }^{21}$ Honorio M. Velasco, «Fotografías escolares, imágenes institucionales», en Antropología audiovisual: medios e investigación en educación, coords. Antonio Bautista y Honorio M. Velasco (Madrid: Trotta, 2011),18.
} 
Un primer nivel de análisis de estas imágenes nos permite preguntarnos sobre la ubicación de estos edificios. Como afirma Antonio Viñao, ${ }^{22}$ su emplazamiento no se erige al azar, sino que está condicionado por múltiples aspectos relacionados con el entorno social y las familias a las que se dirige. En algunos casos, las instituciones privadas se encargan de seleccionar el entorno y, en otros, los benefactores que les donan terrenos y edificios que se encuentran situados en un área urbana, con un contexto sociocultural determinado, estableciéndose una correspondencia clara entre la institución educativa y el grupo social al que va dirigida, en este caso, al alumnado con un nivel económico alto.

Durante el franquismo los colegios religiosos madrileños objeto de estudio ofrecen dos modelos de arquitectura escolar, situación que aparece representada en las fotografías analizadas. Por un lado, colegios con una arquitectura heredada de décadas anteriores como Nuestra Señora del Pilar de Madrid, que ofrecen un modelo arquitectónico monumental representado especialmente a través de fotografías del exterior de los edificios, muy lejos de la imagen de los edificios escolares públicos de los barrios suburbiales del Madrid de la época. ${ }^{23}$

Como se puede apreciar en la fotografía 1, el colegio ocupaba una manzana completa y se articulaba en varios pabellones simétricos con gran luminosidad a través de las galerías que daban al patio central. Conviene precisar que la imagen empleada por el estudiante de Pedagogía para ilustrar el edificio, fue extraída del libro «Bodas de Oro del Colegio del Pilar 1907-1957». Consideramos que esta imagen, encargada a un fotógrafo profesional (vista aérea), ofrece una representación arquitectónica monumental con la que se quería publicitar una identidad escolar de élite social.

\footnotetext{
${ }^{22}$ Antonio Viñao Frago, «Los espacios escolares ¿cómo abordar un objeto polifacético y multiforme?», en Espacios y patrimonio histórico-educativo, coords. Paulí Dávila y Luis M. ${ }^{a}$ Naya (San Sebastián: Erein, 2016), 31.

${ }^{23}$ Es preciso aclarar, que la comunidad educativa marianista antes de asentarse en este edificio monumental, había adquirido una finca frente al Parque del Retiro en la Avenida Menéndez Pelayo, donde tenía proyectada la construcción de un nuevo edificio escolar que respondiera mejor a las crecientes necesidades de espacio por causa de su éxito. Pero antes de iniciarse las obras, recibieron una propuesta de un edificio de estilo neogótico ya construido, de excelentes cualidades arquitectónicas, situado en pleno barrio Salamanca, en la calle Castelló, 50 - posteriormente 56-. El edificio fue proyectado por Manuel Aníbal Álvarez Amorós y construido entre 1908 y 1916. Aunque comenzó a construirse para ser un internado femenino, finalmente la comunidad marianista adquirió el edificio abriendo sus puertas el 23 de octubre de 1921.
} 


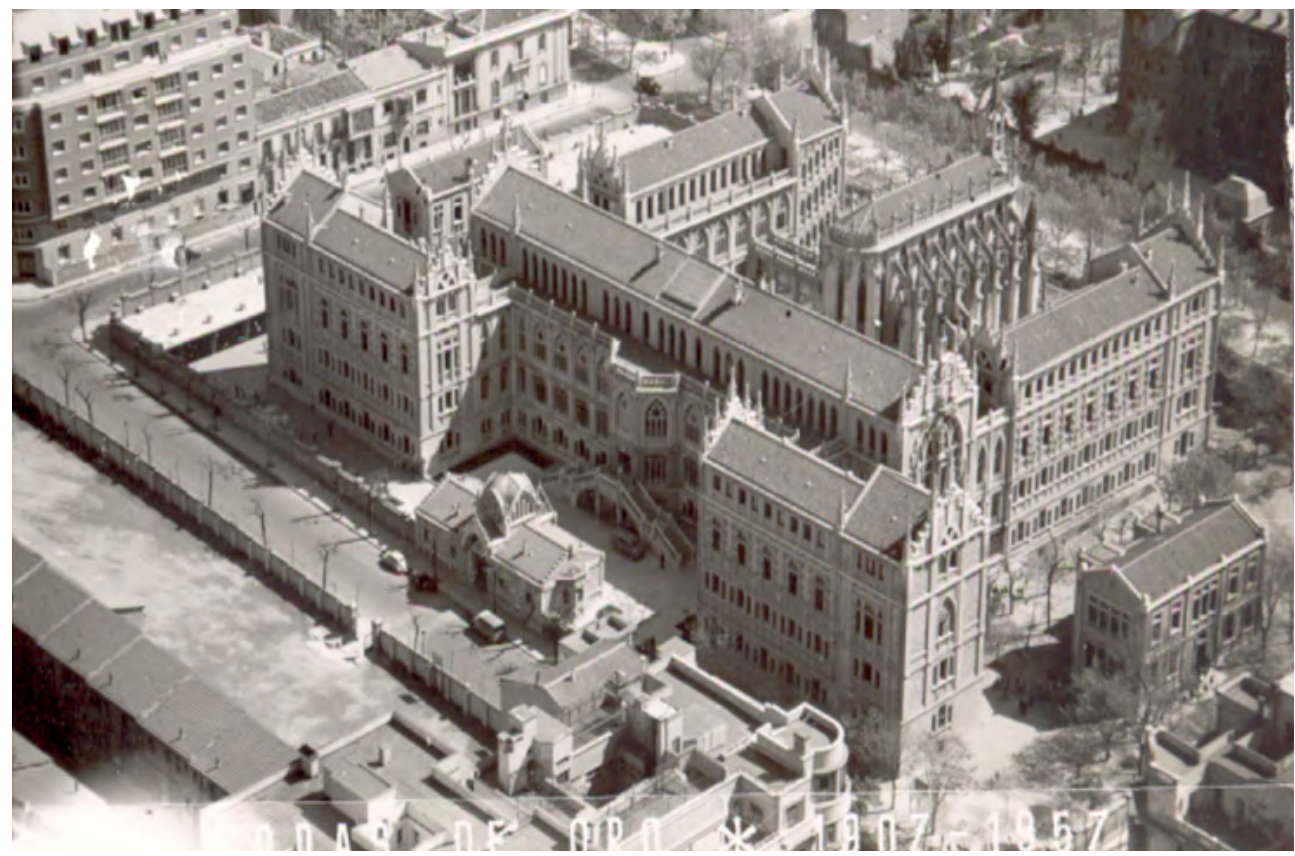

Fotografía 1: Imagen aérea del Colegio Nuestra Señora del Pilar, Madrid, 1957 (FRM 826)

Otro ejemplo de representación espacial, es el que utilizan los Hermanos de las Escuelas Cristianas como eje diferenciador de la oferta educativa elitista ofrecida en el contexto madrileño del franquismo. Concretamente destacamos el Colegio Maravillas, situado en la calle Guadalquivir, en la Colonia el Viso de Madrid. ${ }^{24}$ Tras varias ubicaciones en la capital, se erige en este emplazamiento, bajo unas líneas de construcción más modernas que el Colegio Nuestra Señora del Pilar. Se sitúa entre un conjunto de chalets rodeadas de jardines. Se articula a partir de una galería central. El patio de recreo está situado en la parte opuesta de la fachada principal y está dividido en dos por la capilla y el salón de actos, de forma que así están separados los niños de primaria de los de bachillerato. Como se puede observar en la fotografía 2, también realizada por un profesional, los estudiantes pudieron ilustrar el buen emplazamiento del colegio gracias a una imagen aérea correspondiente a una tarjeta postal:

\footnotetext{
${ }^{24}$ La obra conmemorativa de Antonio Calvo, publicada en 1995, explica detalladamente la historia del Colegio. (Calvo, El Colegio de Nuestra Señora de las Maravillas, 40-61).
} 


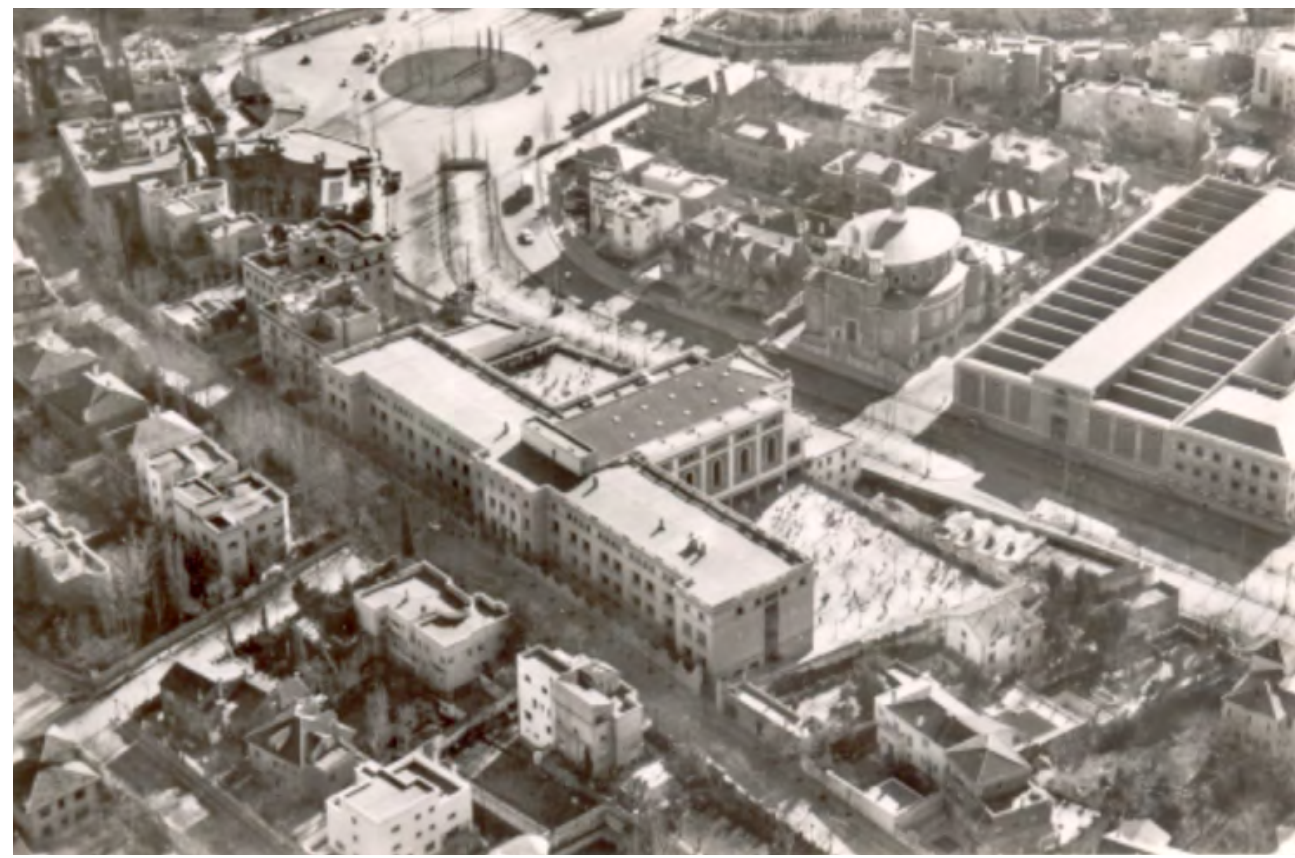

Fotografía 2. Tarjeta postal. Imagen aérea del emplazamiento del Colegio La Salle - Maravillas de Madrid, 1964 (FRM 884)

Estos recursos y posibilidades no estarían al alcance de todos. Los autores de las memorias aportan una estadística en la que mencionan la actividad profesional de los padres de los estudiantes, en su mayoría industriales, abogados, ingenieros, médicos, peritos, etc... ${ }^{25}$ Por tanto, como afirman los autores, la educación de este colegio se dirigía a las familias acomodadas de clase media alta: tan sólo un veinte por ciento disfrutaba de una beca.

Por otro lado, nos encontramos con centros docentes que ofrecen un modelo arquitectónico moderno y vanguardista. El edificio escolar se va a convertir en un claro ejemplo del impacto de los condicionantes políticos, así como de la leve modernización que en el último periodo del franquismo va a vivir la sociedad española. Desde finales de los años cincuenta hasta los inicios de los setenta, la imagen que estas escuelas privadas quieren mostrar entronca con la nueva orientación que va a experimentar la arquitectura escolar en aquel momento. La influencia de

\footnotetext{
${ }^{25}$ Apolinar Martínez y Modesto Barreales, La Salle en el Viso. Estudio de los aspectos formativos de la educación en el colegio Maravillas- La Salle (FRM: 1964), 17-18.
} 
la pedagogía, la psicología y el aspecto social en la definición del espacio escolar van a definir estas edificaciones con las que se pretende atraer a un grupo social burgués de Madrid. ${ }^{26}$

Uno de los ejemplos de este modelo arquitectónico escolar, viene representado por el Instituto Véritas, creado en 1960 por la IT. ${ }^{27}$ En su boletín se recoge un breve balance de la labor educativa de las teresianas en Madrid, con motivo de la celebración del cincuentenario de dicha Institución..$^{28} \mathrm{El}$ Instituto Véritas se erige en una zona residencial a las afueras de Madrid, llamada Somosaguas, perteneciente al municipio de Pozuelo de Alarcón. Se trata de un barrio residencial, segregado de clase alta, tal y como lo ha denominado Ángela García Carballo recientemente en un estudio de carácter urbanístico. ${ }^{29}$ La Urbanizadora Somosaguas concertó con la IT la creación de un colegio que pudiera responder a la demanda social de las familias pudientes, en esta zona residencial de lujo que se estaba generando al final de la década de los años cincuenta. Este centro docente cuenta con una parcela de $35.000 \mathrm{~m}^{2}$, donde se construyeron cinco pabellones aislados, totalmente independientes, con un estilo arquitectónico moderno, sencillo y racionalista. Fue diseñado por los arquitectos Manuel Barbero Rebolledo y Rafael de la Joya Castro, pertenecientes al Movimiento Moderno que se estaba introduciendo en ese periodo en España. También se encargaron de diseñar el colegio de las teresianas en Málaga, que fue galardonado con un premio de arquitectura..$^{30} \mathrm{La}$ construcción se caracteriza

\footnotetext{
${ }^{26}$ Isabel Durá Gúrpide, «La escuela activa en las revistas de Arquitectura», en 4. ${ }^{a}$ Jornadas Internacionales sobre investigación en arquitectura y urbanismo, coord. AA.VV. (Valencia: Universidad de Valencia, 2011), 7.

${ }^{27}$ Durante el primer tercio del siglo xx se crearon diferentes centros docentes en Madrid: la Academia, 1914; el Instituto Católico Femenino, 1924; el Colegio Véritas, 1932. Finalizado el periodo de la Guerra Civil, se fusionaron estos centros en este último, situado en la calle Españoleto, que estuvo funcionando hasta 1970. Debido a la demanda de estudiantes, el Colegio Véritas se fue quedando pequeño y a finales de la década de los cincuenta se proyectó un centro fuera de Madrid, que tuviera unos espacios e instalaciones acordes con la educación que se demandaba en el periodo del desarrollismo español. Del Valle López, «Una pedagogía para la educación integral en la obra de Pedro Poveda», 186.

${ }^{28}$ Agustina De la Peña, «50 años del Instituto Véritas», Boletín informativo de la Federación Pedro Poveda de Asociaciones de Madres y Padres de Alumnos de Centros Educativos Institución Teresiana 16 (2011): 17.

${ }^{29}$ Ángela García Carballo, «Urbanizaciones de lujo y segregación residencial de las clases altas en Somosaguas, Pozuelo de Alarcón (Madrid)», Ería: Revista cuatrimestral de Geografía 94 (2014), 125-144.

${ }^{30}$ M. ${ }^{a}$ José López Martín, «La Academia de Santa Teresa de Málaga (1963). Una propuesta común de arquitectos y pedagogos», en Espacios y patrimonio histórico-educativo. VII Jornadas científicas de la SEPHE y V Simposio Iberoamericano, coords. Paulí Dávila y Luis M. Naya (Donostia-San Sebastián: Universidad del País Vasco, 2016), 117-133.
} 
por módulos flexibles que se adaptan al espacio topográfico, con espacios abiertos o terrazas y galerías que los comunican. La configuración del espacio es muy novedosa, moderna y avanzada para la época. En las fotografías que realizan las autoras de las memorias de prácticas, como amateurs, se pueden apreciar los materiales utilizados en la construcción de los edificios, entre los que cabe señalar, a simple vista, el cemento, el ladrillo, la madera y el cristal. El estilo arquitectónico, tal y como señalan las autoras en el texto, responde a la pedagogía povedana de «luz y verdad», por la importancia de la luz, a través de la metáfora de los cristales y del ladrillo, porque apoyándose «unos en otros, seguros, sin perder el sello individual, pretenden ser una sociedad unida» ${ }^{31}$

Afirmación que hemos comprobado con las fuentes orales consultadas. ${ }^{32}$ El concepto de verdad (Véritas) venía asociado al de libertad. Como premisa, la IT siempre tuvo presente la idea de que si no hay libertad, la persona no puede manifestarse verdaderamente. Según los testimonios proporcionados por estas profesoras, una de las directoras provinciales de la IT, Carmela Álvarez, fue «el cerebro de este centro, tuvo la innovadora idea de trabajar con los arquitectos. Les facilitó los textos del Padre Poveda para que entendieran su pedagogía». El edificio se plantea, como reflejan las fotografías 3 y 4 tomadas por la estudiante, a partir de una construcción con pabellones y galerías abiertas, que eviten las aglomeraciones de las alumnas, sin puertas de seguridad y en contacto con la naturaleza. Las clases debían estar orientadas al sur,

porque la luz debía estar presente en todos los sentidos, de ahí la importancia de los grandes ventanales. Se eligió el ladrillo por la sencillez del material y porque no se pretendía que fuera una edificación ostentosa. El blanco de las paredes representaba la pureza de la persona. El corcho de las aulas simboliza la creatividad como medio de expresión de los estudiantes a través de sus trabajos y proyectos educativos, murales, etc. ${ }^{33}$

\footnotetext{
${ }^{31}$ Emilia Domínguez Rodríguez, Estudio general del Instituto Véritas y especial sobre la enseñanza primaria del referido centro (FRM 13, 1964), 10.

${ }^{32}$ Se ha contado con la colaboración testimonial de una ex-directora, Antonia García, una profesora de inglés, Carmen Sánchez, y con una de las autoras de la memoria, Emilia Domínguez, antigua profesora del Véritas, a las que queremos extender nuestro agradecimiento por las entrevistas, el material y la información facilitada.

${ }^{33}$ Testimonio de Carmen Sánchez, profesora de inglés del Instituto Véritas.
} 

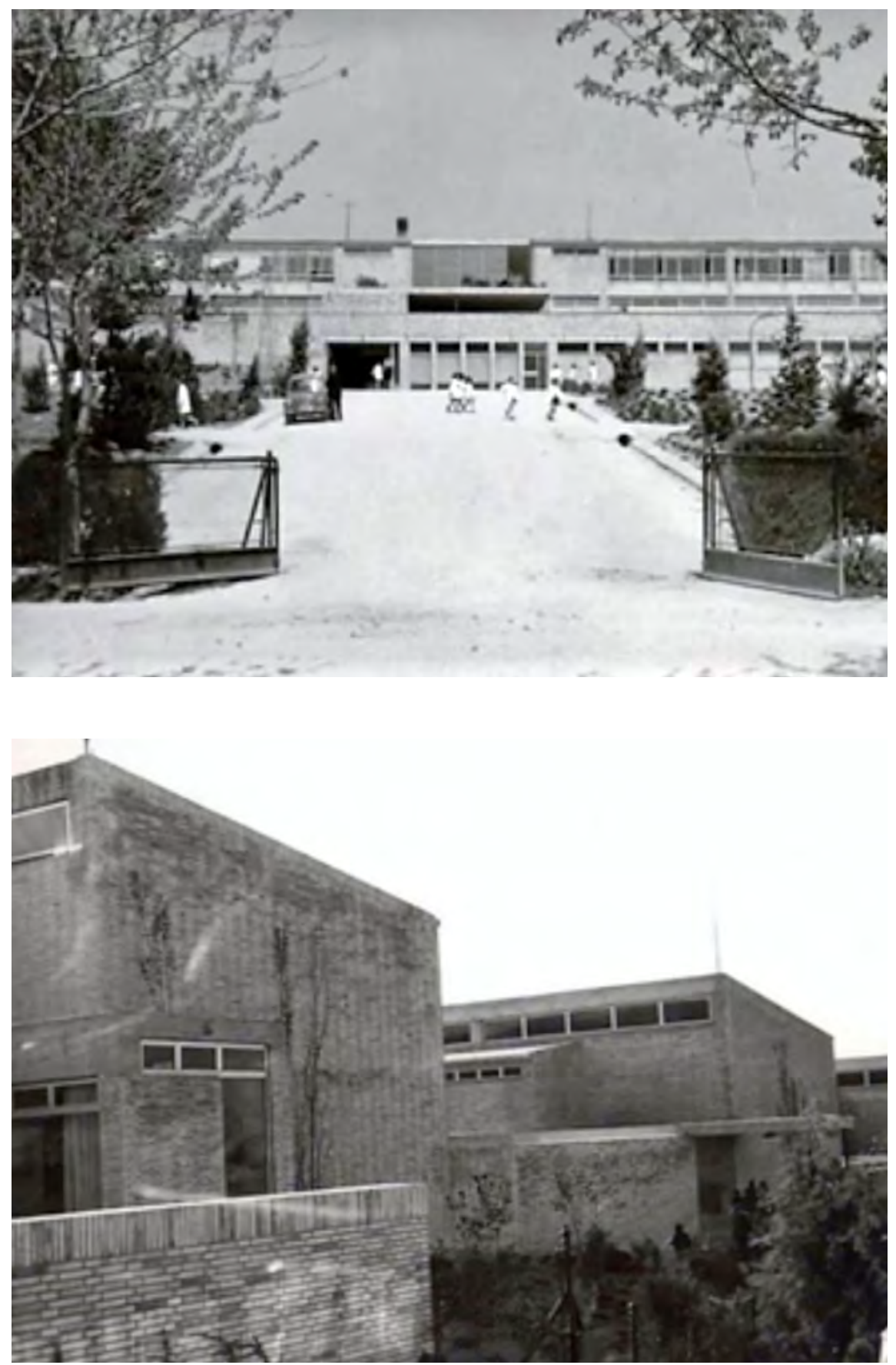

Fotografía 3 y 4. Recinto y fachada del Instituto Véritas, Madrid, 1964 (FRM 13) 
En las imágenes que aparecen en estas memorias se representan unos edificios sencillos, modernos con espacios abiertos, donde se aprecia un cambio de modelo arquitectónico que contempla nuevas formas de plantear la enseñanza. Como puede observarse en las imágenes inferiores, también de amateur (Fotografías 5 y 6), las aulas se abren al exterior en terrazas que permiten dar clase al aire libre, con grandes ventanales, jardines recubiertos de piedras guijarros con distintas plantas y flores. Respecto a la utilización de estos espacios abiertos (obsérvense las fotografías 5 y 6), una profesora y autora de la memoria nos confirmó que se utilizaban frecuentemente con las alumnas:

Se usaban con asiduidad, al menos yo, para actividades que tenían que ver con lo aprendido en el aula: leçons des choses decíamos, a lo relacionado con geografía y naturaleza (siguiendo libros, preferentemente franceses, editados con este nombre), y también para descansar o jugar en un determinado momento de las horas lectivas, si se consideraba oportuno. ${ }^{34}$

Otro ejemplo de arquitectura moderna que podemos encontrar en las memorias de prácticas es el Colegio Santa María del Pilar, fundado en el año 1955 y perteneciente a la congregación marianista. Se trata de una Sección del Colegio Nuestra Señora del Pilar (denominada Sección-Jardín) situado en el barrio del Niño Jesús, destinada a los hijos de antiguos alumnos del Pilar. Inicialmente el proyecto de edificación presentado por el arquitecto Luis Moya Blanco apostó por un modelo constructivo clásico al estilo monumental del Pilar, pero el anteproyecto de José Antonio Domínguez fue el seleccionado para ser construido por ser más funcional, moderno y abierto. Durante esos años Madrid sufriría una gran transformación al pasar de ser la capital administrativa a ser centro industrial de primer orden, lo que favoreció que los colegios marianistas vivieran una década de máximo esplendor. Como se puede observar en las fotografías 7 y 8 - correspondientes a recortes de imágenes,

\footnotetext{
${ }^{34}$ Entrevista realizada a Emilia Domínguez Rodríguez, autora de la memoria y profesora del tercer curso de primaria del Instituto Véritas. También fue ex-alumna brillante del colegio Véritas situado en la calle Españoleto. Simultaneó su labor docente en el Instituto Véritas con los estudios de Pedagogía. Posteriormente se trasladó a Cáceres, donde consiguió ser Catedrática de Teoría e Historia de la Educación en la Universidad de Extremadura.
} 

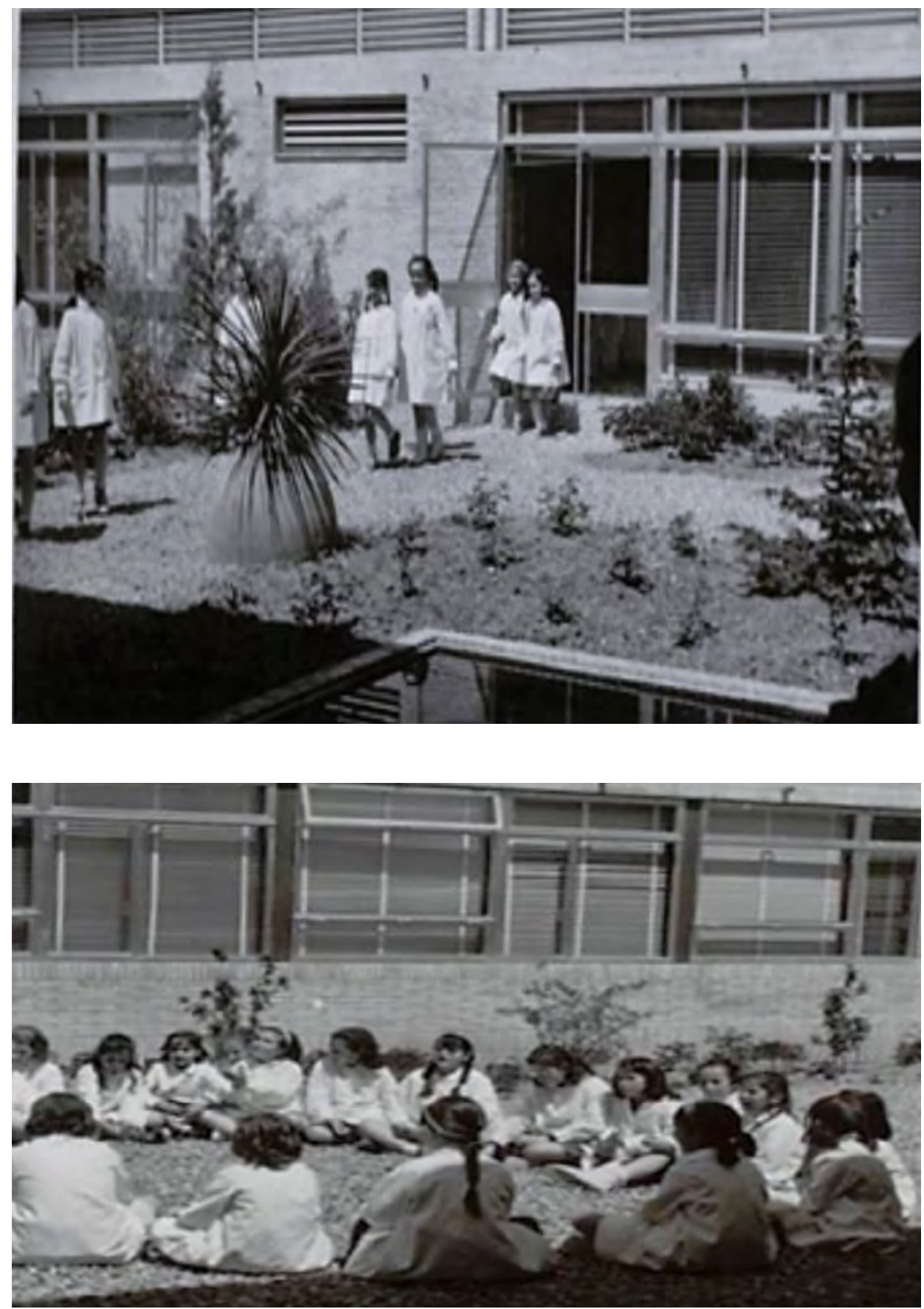

Fotografías 5 y 6. Terrazas de las aulas del Instituto Véritas, Madrid, 1964 (FRM 13) 
realizadas por un profesional, procedentes de las memorias oficiales del colegio-, las instalaciones del centro docente representan una arquitectura más moderna, con amplios ventanales que dejan pasar la luz, pasillos cubiertos al aire libre que conectan los diferentes pabellones del centro y zonas ajardinadas. Es un diseño arquitectónico que claramente trató de romper con el clasicismo de otros centros privados. El propio autor de la memoria de prácticas, insiste en que «no hay ningún elemento que recuerde a una fachada monumental, ni a una entrada principal», y por ello está construido en hormigón armado, piedra caliza, aluminio, hierro y ladrillo visto. ${ }^{35}$
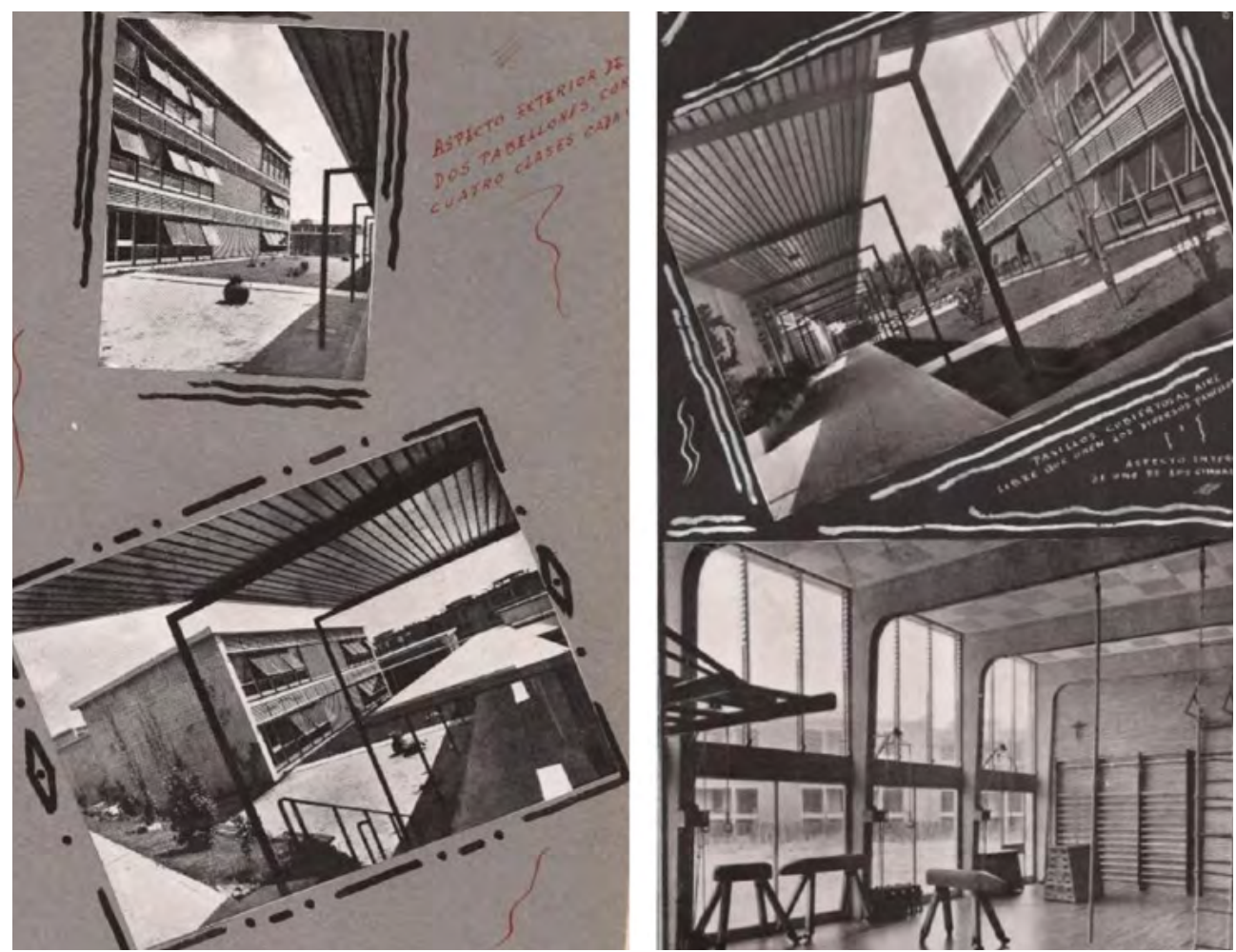

Fotografías 7 y 8. Instalaciones del Colegio Santa María del Pilar, Madrid, 1965 (FRM 092)

\footnotetext{
${ }^{35}$ Félix Caja Pablo, Trabajo de prácticas. Colegio Santa María del Pilar, (FRM 92: 1965), 56.
} 
Las fotografías ofrecen una relación directa entre sus instalaciones y el programa escolar moderno que ofrecen — del que hablaremos más adelante- - Se representan edificios de grandes dimensiones en los que se concede una gran importancia a los espacios exteriores, jardines, patios de juego y espacios para el deporte.

En definitiva, podríamos decir que hay una revalorización del espacio exterior de los centros educativos. Tratan de ofrecer una concepción social de la escuela que iba más allá de la instrucción, atendiendo a las necesidades fisiológicas y afectivas del niño, bajo una jerarquía espacial que contempla áreas de encuentro que transforman los espacios de circulación en lugares de relación. ${ }^{36}$

\section{La representación de la religiosidad}

El concepto de educación integral aparece íntimamente ligado a la religiosidad. La formación humana y cristiana resultan ser dos aspectos básicos de la educación en estos centros, que se proyectan en la actividad escolar diaria de las escuelas lasalianas, marianistas y de la IT de Madrid. Coincidiendo con las afirmaciones de Dávila y Naya, la manifestación de la religiosidad se convierte en una práctica habitual y extendida en estos centros religiosos, a través de actividades de apostolado como la eucaristía o la devoción mariana, que se articulan y desarrollan integradas dentro de la vida escolar y extraescolar a través de diferentes asociaciones que van creándose ${ }^{37}$ como la Congregación de la Inmaculada o de San Juan Bautista; la Cruzada Eucarística, la Congregación la Archicofradía del Santísimo Niño Jesús o la Acción Católica, entre otras. Estas escuelas suponían un contexto privilegiado para ello y se visibilizaba en manifestaciones de carácter público y privado. Por tanto, la religiosidad representa una seña de identidad de los colegios católicos privados madrileños y se manifiesta de diversas formas a través de las fotografías.

Por un lado, nos encontramos con un grupo importante de fotografías que son un ejemplo de manifestación de la religiosidad pública. En

\footnotetext{
${ }^{36}$ Durá Gúrpide, «La escuela activa en las revistas de Arquitectura», 9.

${ }^{37}$ Dávila, Naya y Murua, «Prácticas y actividades religiosas en los colegios privados del País Vasco durante el siglo xx», 146.
} 
ellas, las fotografías de las iglesias y las capillas denotan el lugar privilegiado que ocupan dentro del espacio escolar. El edificio aparece anejo al resto de instalaciones cobrando así un protagonismo excepcional, ofreciendo en un primer plano una visión monumental tanto de los exteriores de la iglesia como de la capilla interior del colegio. La imagen que ofrece este grupo de fotografías entronca con el discurso propagandístico que estas escuelas privadas quisieron transmitir consolidando un imaginario colectivo e identitario diferenciado. A modo de ejemplo, mostramos la siguiente fotografía de la que podemos hacer algunas observaciones. En primer lugar, la monumentalidad del edificio, que un fotógrafo profesional, contratado por el propio colegio, retrata de la Iglesia del Colegio Santa María del Pilar - concretamente el estudio fotográfico Lozano, a quien se debe gran parte de fondo fotográfico del Colegio Nuestra Señora del Pilar y el Colegio Santa María del Pilar-. En segundo lugar, representa un acto religioso público, integrado dentro de la vida escolar del centro, siendo un elemento más de garantía de la enseñanza religiosa que tiene como principal fin introducir al estudiante en la vida cristiana:

la instrucción religiosa es la primera, la más necesaria, la más útil y de todas las maneras la más práctica de todas las disciplinas. Puede decirse que el porvenir temporal y eterno del niño, depende en gran parte de cómo haya sido esta enseñanza religiosa. Basta con esa consideración para que el religioso de María ponga todo empeño por sobresalir en la enseñanza de esta disciplina, hacerla interesante. ${ }^{38}$

En tercer lugar, la dimensión pública de la imagen entronca con una imagen social determinada al visibilizar a una multitud de feligreses que están realizando uso de dicho espacio. Tal y como recoge el autor de la memoria, la imagen (fotografía 9) ha capturado un día de misa dominical a la que asisten familias y alumnos, una práctica religiosa muy habitual en estas escuelas que garantiza la implicación de las familias en las labores catecúmenas.

\footnotetext{
${ }^{38}$ Jesús Ayuso Arroyo, Estudio de la labor formativa del Colegio del Pilar de Madrid, 1957 (FRM 826), 74.
} 

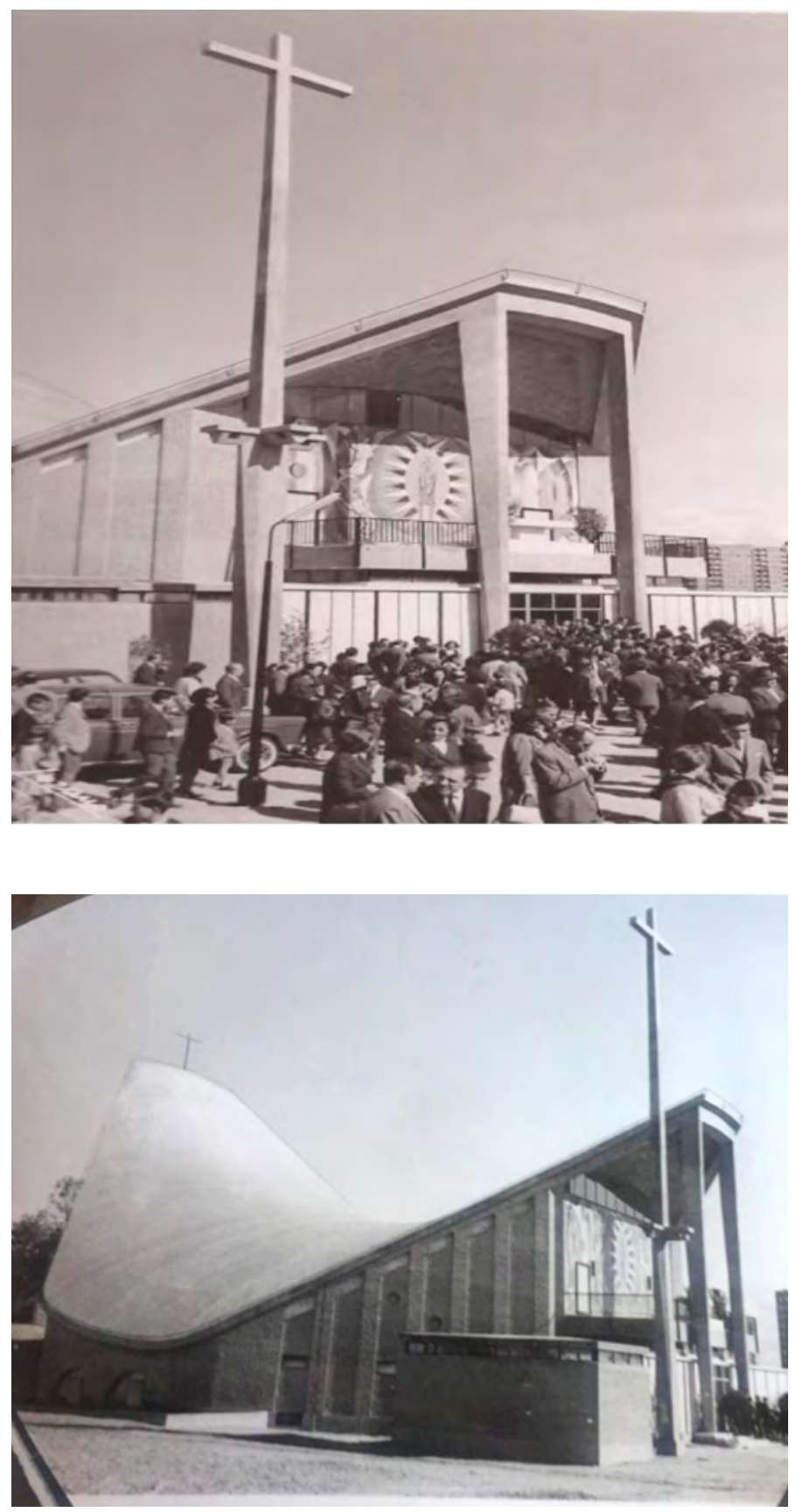

Fotografías 9 y 10: Iglesia del Colegio Santa María del Pilar. Fotografías firmadas por el fotógrafo profesional Lozano, Madrid, 1965 (FRM 092) 
Al igual que en la imagen anterior, en este caso de interiores de las iglesias del Colegio Maravillas y de la Iglesia de Santa María del Pilar, las fotografías 11 y 12 seleccionadas por los estudiantes de Pedagogía —realizadas por fotógrafos profesionales - tratan nuevamente de visibilizar la participación activa de la comunidad escolar en la vida religiosa del centro.
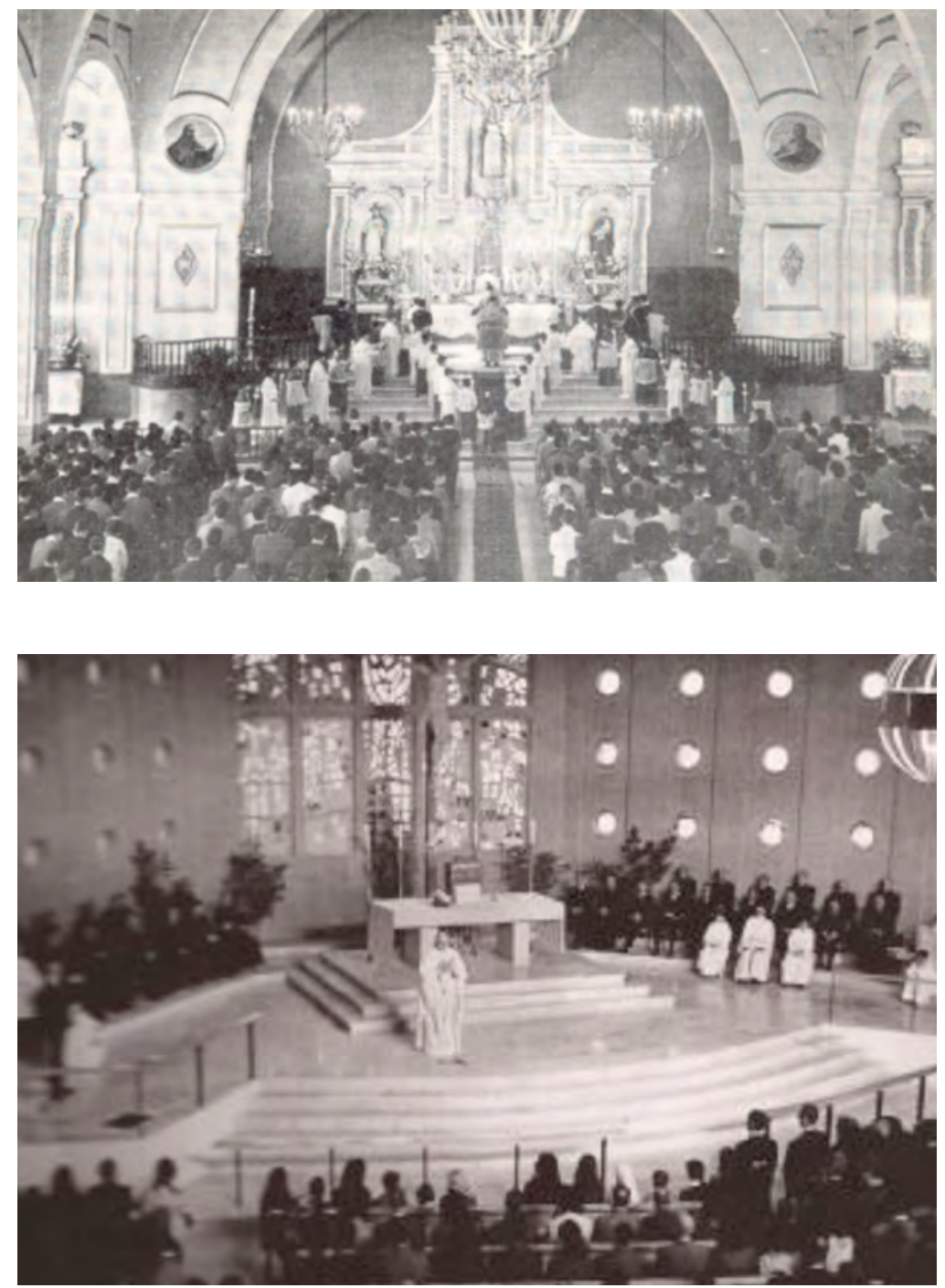

Fotografías 11 y 12. Izquierda: Iglesia del Colegio Maravillas-La Salle, 1964 (FRM 884); Derecha: Iglesia del Colegio Santa María del Pilar, 1964 (FRM 092). 
Por otro lado, existe un grupo de fotografías que identificamos con el desarrollo de una religiosidad privada. Claro ejemplo de esta religiosidad lo ofrece el Instituto Véritas, representando una orientación muy alejada de las anteriores escenografías sobre el culto religioso. Podemos afirmar que la IT se identifica con un carácter más intimista de la religión. Estas dos fotografías, realizadas por la autora de la memoria (12 y 13), en las que aparece sólo una niña orando frente a una estatua de la Virgen en un lugar visible, o besándola, denotan que la devoción a la Virgen del Fiat formaba parte del ideario educativo y religioso de esta Institución, pero con una manifestación más cercana a la religiosidad individual y personal. ${ }^{39}$ Interpretación que viene avalada por la explicación que una de las autoras de las memorias realiza en el texto.

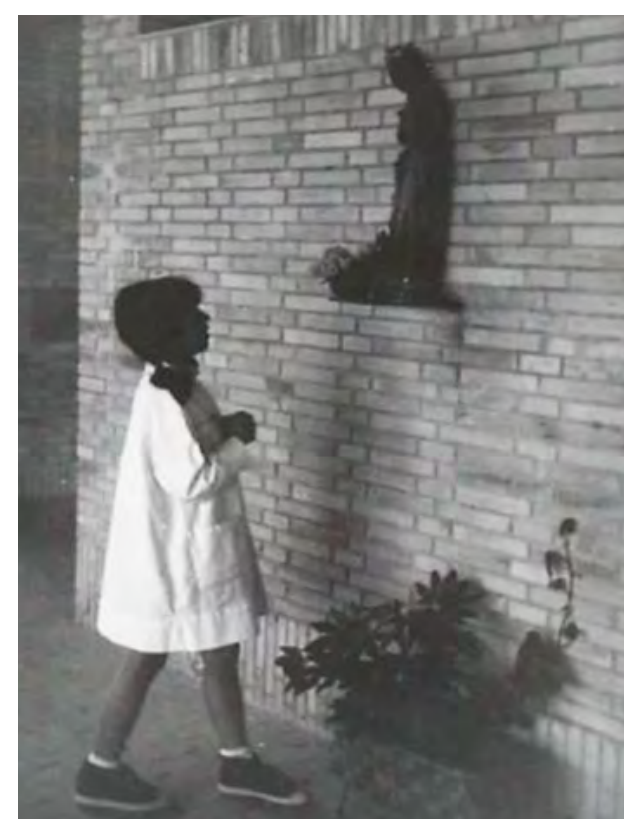

\footnotetext{
${ }^{39}$ Una de las profesoras entrevistadas, Carmen Sánchez, menciona que Josefa Segovia, colaboradora del Padre Poveda, fue la promotora de otorgar este nombre a la Virgen, como símbolo de la encarnación de Cristo. La Virgen del Fiat representa el símbolo de la identidad religiosa del colegio, es la patrona del Instituto Véritas. Uno de los rasgos distintivos e identitarios de los colegios religiosos es la devoción a una virgen o un santo de esa congregación o institución. Como señalan Dávila y Naya, con motivo de la celebración del año mariano en 1954, los centros religiosos incorporan la Virgen María al imaginario colectivo y a las prácticas educativas. Dávila, Naya y Murua, «Prácticas y actividades religiosas en los colegios privados del País Vasco durante el siglo XX», 148.
} 


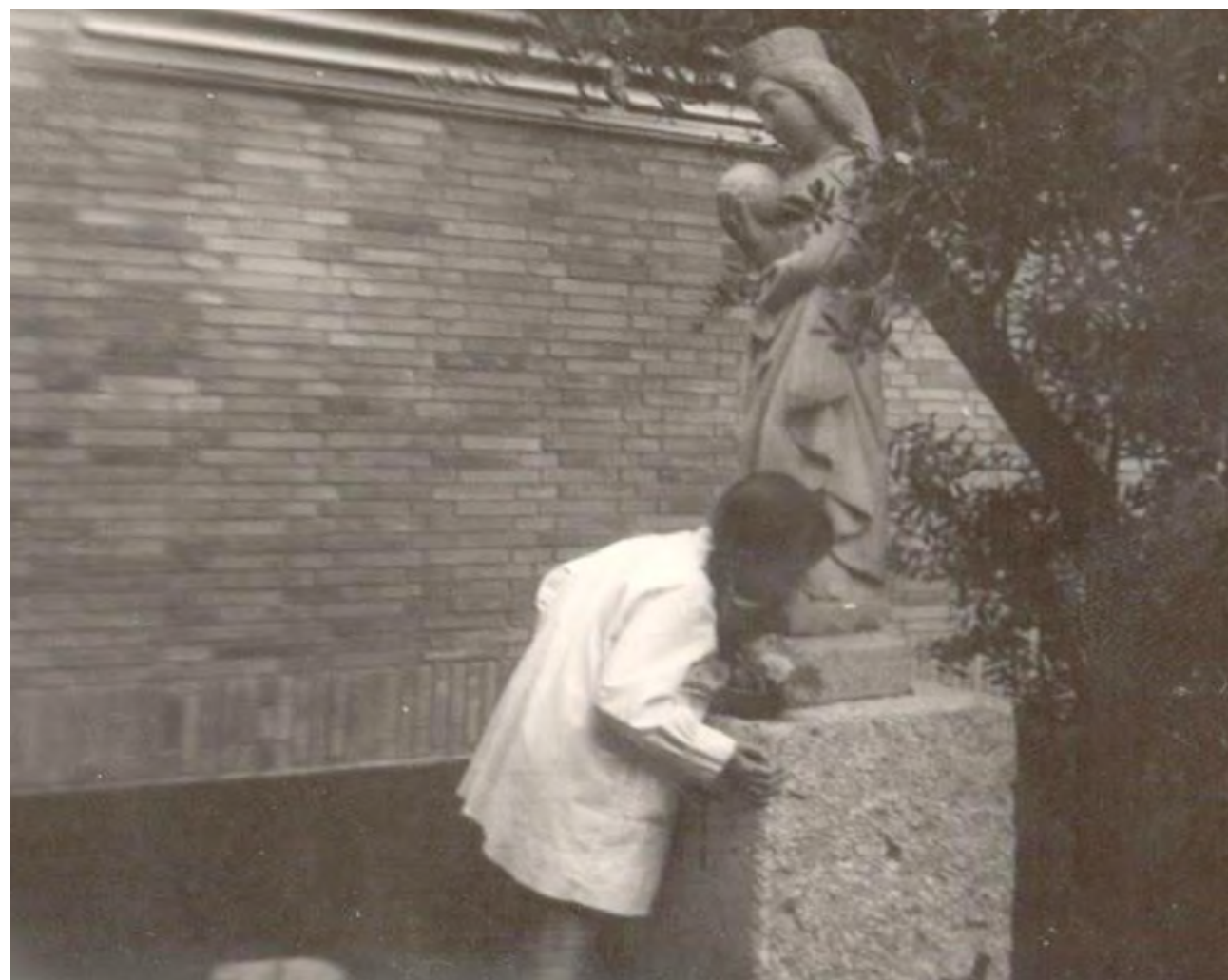

Fotografías 12 y 13. Niñas rezando/besando a la Virgen del Fiat en el Instituto Véritas, Madrid, 1964, (FRM 13), 1966 ( FRM 852).

En las dos memorias de prácticas analizadas sobre el Instituto Véritas no se incluye ninguna imagen sobre la capilla del centro. Esta invisibilidad gráfica queda explicitada en el texto de forma indirecta, debido a que una de las autoras manifiesta en el año 1964 el carácter provisional del espacio asignado, a pesar de detallar todas las actividades de culto que se realizaban. ${ }^{40}$ Resulta curioso que en un edificio de reciente construcción, la capilla no fuera el elemento prioritario en la arquitectura escolar del colegio, como lo fue en el resto de colegios referenciados.

\footnotetext{
${ }^{40}$ Dos años más tarde, María Jesús Maestro menciona el traslado de la capilla a la sala de conferencias del colegio de forma temporal, aunque se especifica que está prevista su ubicación en un lugar central del edificio. Maestro García, Estudio general sobre el Instituto Véritas y su enseñanza individualizada en los cursos: $1^{\circ}, 2^{\circ}$ y $3^{\circ}$ de primaria, 10.
} 
Otra interpretación que se nos ocurre, tiene que ver con el discurso del relato que nos quieren transmitir las profesoras al elegir las escenas más íntimas: la devoción de las alumnas a la Virgen del Fiat, no tiene que ser un acto social, sino que, desde la libertad, se puede hacer tantas veces como se desee. Pensamos que la propuesta de construir un pequeño altar, adaptado a la estatura de las niñas en los espacios comunes del edificio, ofrece la posibilidad de vivir la religiosidad de una forma más cercana, próxima e íntima, donde se pueden acercar las alumnas de todas las edades. Nos parece que pretenden aplicar el principio pedagógico montessoriano a todos los símbolos identitarios del colegio.

En otro orden de cosas, aunque en consonancia con la simbología religiosa, se observa una ausencia de retratos patrióticos en las aulas de los colegios privados. La obligatoriedad de la simbología patriótica y religiosa en las aulas fue uno de los requisitos legales que determinó la decoración de las paredes de todas las aulas franquistas, presididas por un crucifijo, una imagen de la Inmaculada y los retratos de Francisco Franco y José Antonio Primo de Rivera. Si bien en los primeros años de la dictadura esta simbología estuvo muy presente, desde mediados de los años cincuenta y sesenta las fotografías no reflejan esa realidad y nos sugieren, por un lado, formas de resistencia a la autoridad que imponía una decoración monolítica de las aulas, contraviniendo las disposiciones oficiales y pasando desapercibida la simbología patriótica; y, por otro lado, que la simbología identitaria de la propia congregación — banderas del colegio, insignias, himnosocupan un primer plano relegando a un segundo escenario la simbología patriótica del régimen, aunque en algunos casos coincidiera con los valores del del mismo. En este sentido, parece que estos centros gozaron de una mayor autonomía que los centros públicos al no estar tan controlados por la inspección educativa. Como ya se ha recogido en un trabajo anterior, ${ }^{41}$ las imágenes nos permiten visibilizar silencios y ausencias materiales que han permanecido ocultos y que eran chocantes en la España franquista.

\footnotetext{
${ }^{41}$ Del Pozo y Rabazas, «Imatges fotogràfiques i cultura escolar».
} 
La representación de las actividades como elementos de identidad y distinción

La representación visual de este tipo de colegios se dirige a mostrar unas instalaciones ostentosas, modernas y, desde una perspectiva pedagógica, que introducen recursos y actividades innovadoras, equiparables a las de cualquier colegio europeo e internacional. Las labores de marketing de estos centros se dirigieron hacia su proyecto educativo y giraron en torno a cuatro elementos: los recursos que contaban para la enseñanza científica, la actividad física y deportiva, la oferta educativa de actividades artísticas y el movimiento asociativo de ex-alumnos.

En primer lugar, podemos destacar los recursos y materiales vinculados a las modernas pedagogías y a una formación más científica, representada en las fotografías de museos específicos. Del Colegio Maravillas se hace alarde de los Museos de Ciencias Naturales o Física y Química tratando de visibilizar los medios tan innovadores que poseían para la enseñanza de estas materias. Se ofrecían como espacios de una gran utilidad pedagógica que eran empleados para complementar las clases teóricas.

En la fotografía 14 se aprecia una selección de minerales y animales de gran variedad. En las observaciones de los autores de la memoria se explica que el alumnado podía realizar trabajos científicos como «complemento eficacísimo de la formación teórica. Por medio de estos trabajos los alumnos se familiarizan con la técnica y se aficionan a la investigación ». ${ }^{42}$ No cabe duda que la formación intelectual ofertada en éstos tuvo un carácter propedéutico o de continuidad con los estudios superiores, donde el alumnado estaba abocado a la universidad.

El Colegio el Pilar también contaba con un Laboratorio de Química, un Gabinete de Física, y un laboratorio o Museo de Historia Natural. Estos museos se dotaron de materiales procedentes de Berlín, Viena o París, logrando tener importantes colecciones. En concreto, el Museo de Ciencias Naturales fue promovido por uno de sus directores (fotografía 15), el Padre Heintz, que compró una colección biológica de Santander además de recibir donaciones de ex-alumnos. ${ }^{43}$

\footnotetext{
${ }^{42}$ Martínez y Barreales, La Salle en el Viso. Estudio de los aspectos formativos de la educación en el colegio Maravillas-La Salle, 49-50.

${ }^{43}$ José Luis Sánchez Martín, «Los años cuarenta (1939-1950)», en El Pilar, cien años de historia, 108.
} 

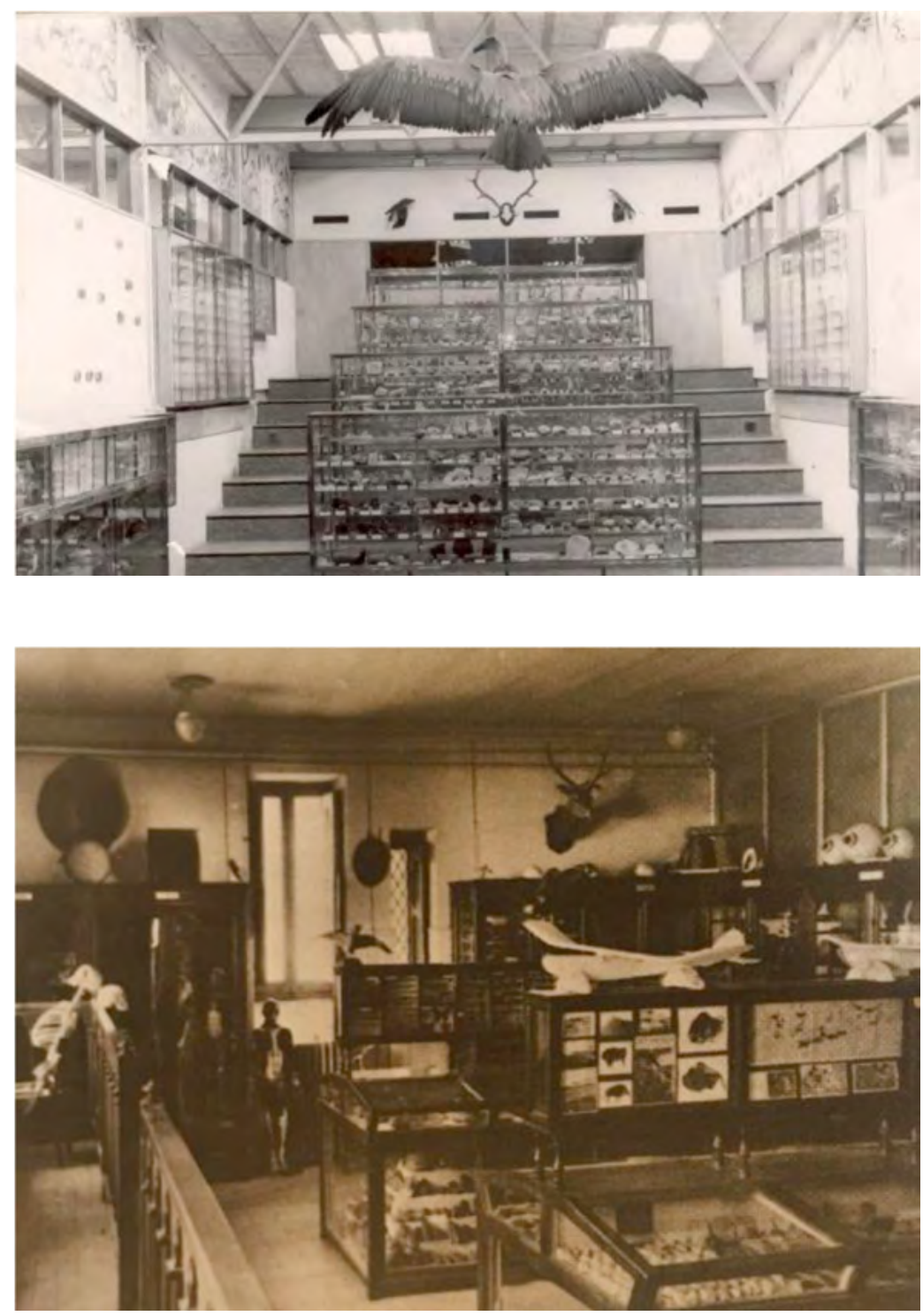

Fotografías 14 y 15. Izquierda: Museo de Ciencias Naturales del Colegio Maravillas-La Salle, Madrid, 1964 (FRM 884). Derecha: Laboratorio de Ciencias Naturales del Colegio El Pilar, Madrid, 1962,

(FRM, 826). Ambas imágenes están realizadas por un fotógrafo profesional.

Las escuelas lasalianas pusieron en marcha métodos modernos basados en una enseñanza más intuitiva. Por ejemplo, a través de la organización de numerosas exposiciones escolares trimestrales y anuales, en las 
que el alumnado participaba para mostrar el trabajo realizado durante el curso. En la fotografía 16, extraída de una Memoria del Centro, puede apreciarse cómo los estudiantes de segundo de bachillerato exponen sus trabajos de educación religiosa: ${ }^{44}$
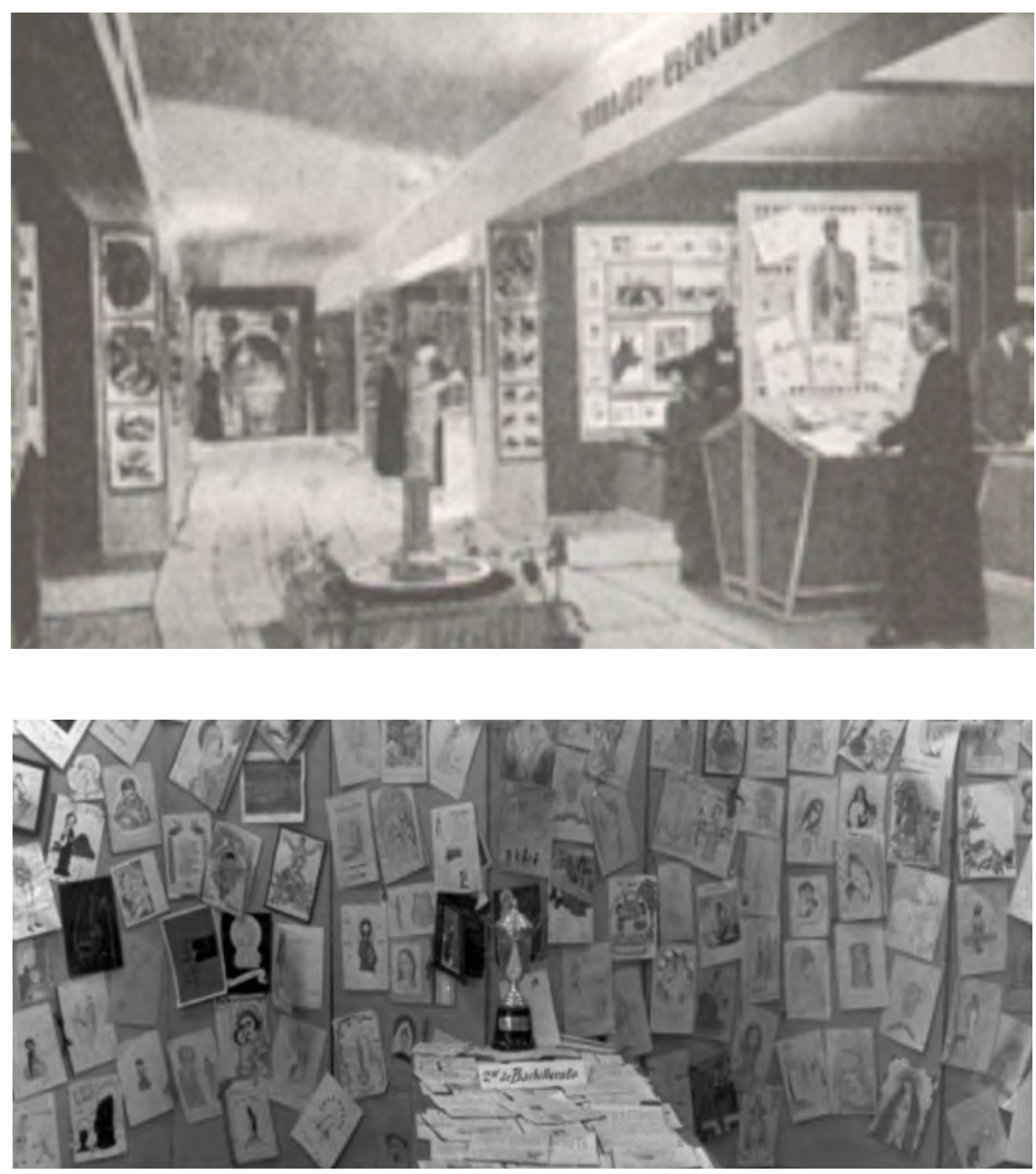

Fotografías 16 y 17. Exposiciones escolares del Colegio Maravillas-La Salle, 1964 (FRM 884). La imagen de la derecha está realizada por el estudiante, autor de la Memoria.

\footnotetext{
${ }^{44}$ Estas innovaciones educativas se complementaban con la realización por parte de los alumnos de periódicos murales, o la puesta en marcha de cine científico procedente de los Ministerios de Industria y Agricultura o de las embajadas de Estados Unidos, Inglaterra, Francia, etc.
} 
Otro elemento distintivo de estos colegios es la práctica de los deportes como una representación simbólica de distinción (Fotografía 18), que marcaba la diferencia con los centros públicos, verificando el concepto de distinción social que realiza Bourdieu. ${ }^{45}$ El deporte suponía una práctica elitista, que se introdujo en las Public Schools inglesas —instituciones educativas masculinas de la aristocracia y la alta burguesía- y proporcionaba un modo de control y educación moral para los alumnos que formarían en un futuro la clase dirigente, a través de valores como el coraje, y de desarrollar el carácter, inculcar la voluntad de ganar y la necesidad del esfuerzo y del entrenamiento sistemático para conquistar las metas del llamado «Cristianismo masculino». ${ }^{46}$

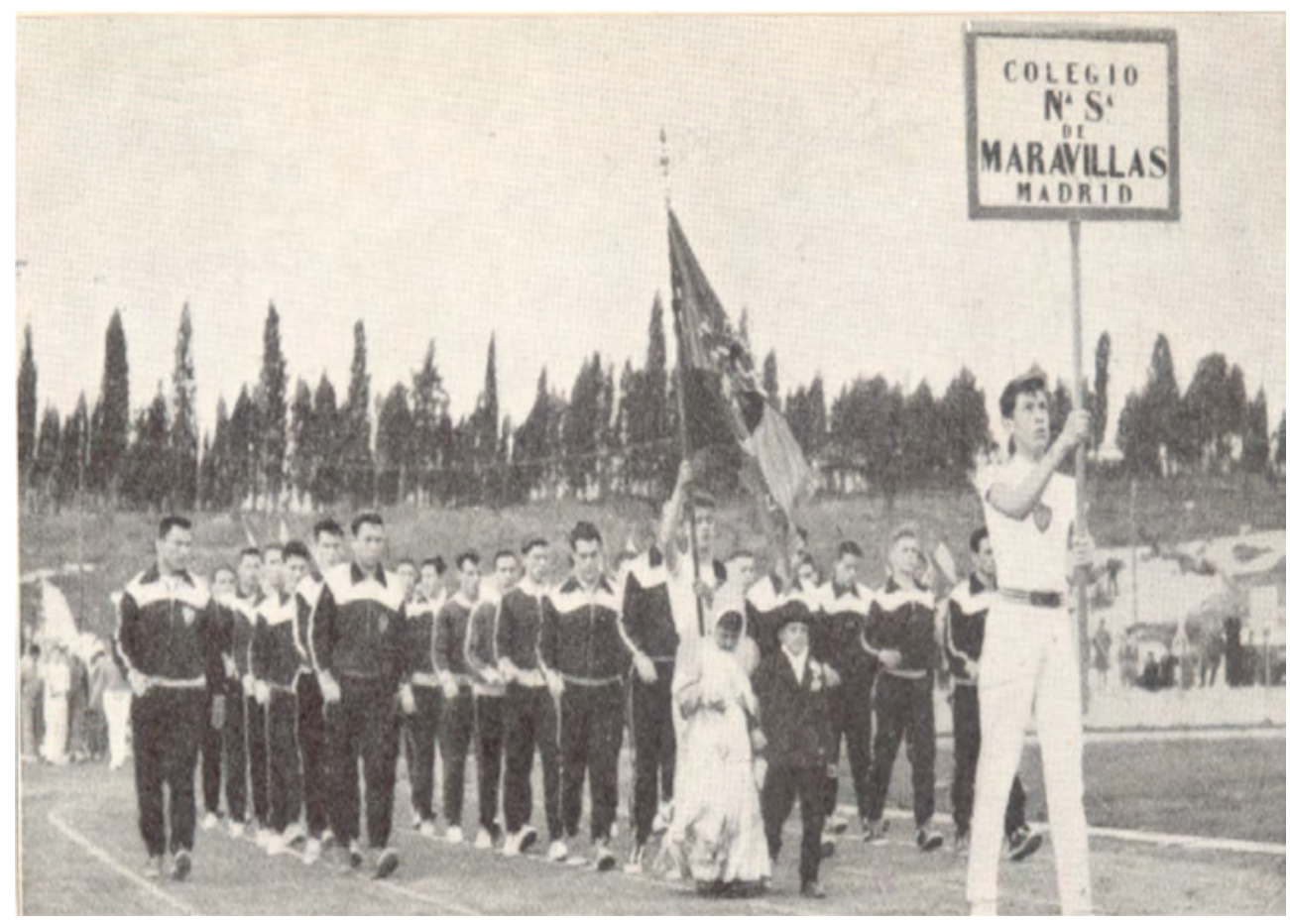

Fotografía 18. Campeonato deportivo con la participación del alumnado del Colegio Maravillas, 1967 (FRM 884). Imagen realizada por un fotógrafo profesional.

\footnotetext{
${ }^{45}$ Pierre Bourdieu, «Deporte y clase social», en Materiales de sociología del deporte, ed. José Ignacio Barbero (Madrid: La Piqueta, 1993), 57-82.

${ }^{46}$ J.A. Mangan, Athleticism in the Victorian and Edwardian Public School (Lewes: Falmer Press, 1981). Referencia citada en Dávila, Naya y Zabaleta, «Memory and Yearbooks», 73.
} 
Por tanto, el deporte representa un símbolo de identidad y de pertenencia a la institución escolar. La participación en campeonatos con otros colegios, organizados en muchas ocasiones por el Frente de Juventudes, suponía fomentar un espíritu de camaradería con los compañeros, pero también favorecía un espíritu de rivalidad y competición con otros colegios pertenecientes a otras congregaciones religiosas. En palabras de José Antonio Elola, Delegado Nacional de Deportes en los años cincuenta:

el colegio del Pilar ha cuidado con esmero la educación física de sus colegiales, teniendo a la vista la consideración de que la educación física no es una parte, siquiera importante, del deporte, son el todo del deporte, del que constituye su propia raíz y médula. Ha comprendido que, quiérase o no, los resultados obtenidos en las competiciones deportivas han llegado a ser hoy en día una especie de barómetro que da la medida del progreso y del nivel de las naciones. [...] En resumen, que el Colegio del Pilar considera el deporte como un hecho social de suma importancia. ${ }^{47}$

Como se puede observar en las fotografías 19 y 20. la imagen deportiva de estas escuelas dibujaba una clara maniobra de marketing escolar y contribuía a ofrecer una identidad diferenciada de la comunidad educativa que representaban. Paradójicamente, estas imágenes corresponden a dos escuelas diferentes, pero, como se puede observar, los elementos que componen la escenografía están dispuestos de la misma manera en el espacio. ${ }^{48}$

El tipo de deportes que se practicaba en estas escuelas tenía un carácter claramente elitista. Inicialmente la práctica del fútbol y el baloncesto fue la más extendida; de hecho, en la gran mayoría de las memorias aparecen fotografías de niños jugando al fútbol, pero de forma progresiva estos centros irían introduciendo deportes poco frecuentados por las clases populares como el hockey sobre hierba (fotografía 21), sobre patines, la esgrima o la gimnasia deportiva.

\footnotetext{
${ }^{47}$ AA.VV., El Pilar, cien años de historia, 153-154.

${ }^{48}$ No podemos pasar por alto el escudo del águila imperial que aparece en el Colegio Maravillas-La Salle. Seguramente esta escena pertenece a un campeonato organizado por el Frente de Juventudes y el centro debió incluir el símbolo patriótico por imperativo político.
} 


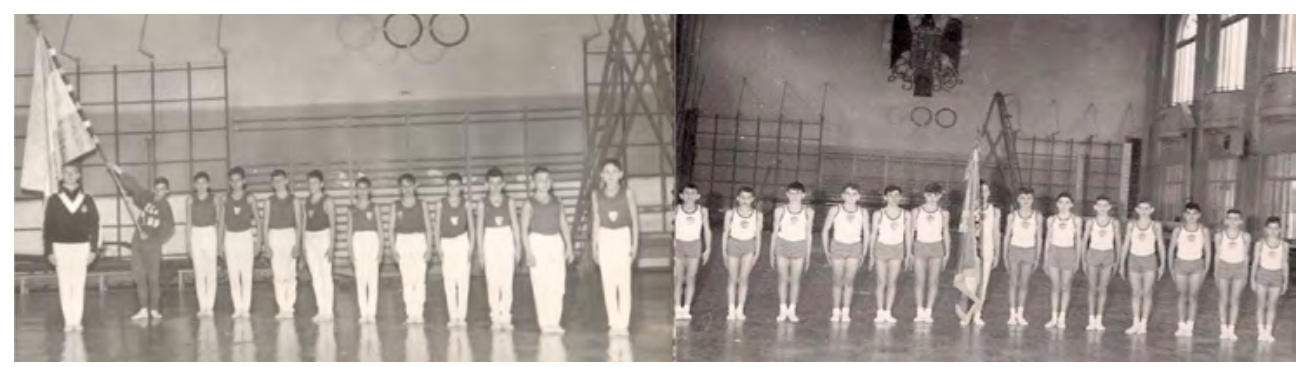

Fotografías 19 y 20. Izquierda: Equipo de gimnastas del Colegio Maravillas-La Salle (revista Perseverancia); Derecha: Equipo de gimnastas deportivos del Colegio El Pilar, Madrid, 1962 (FRM 882).

Imágenes realizadas por fotógrafos profesionales.

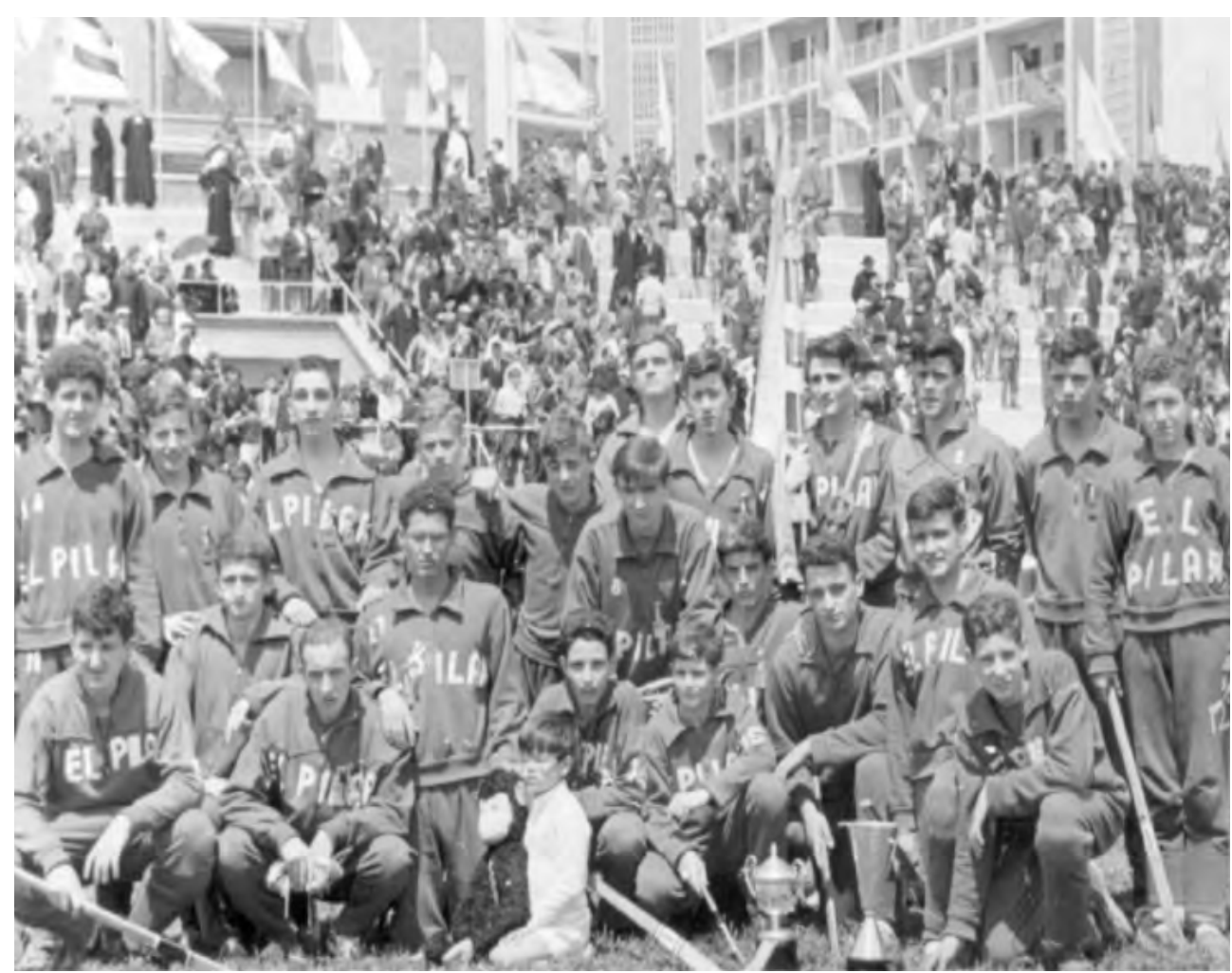

Fotografía 21. Equipo de Hockey sobre hierba del Colegio El Pilar, Madrid, 1962 (FRM 882). Imagen realizada por fotógrafo profesional. 
Relacionada con el deporte, la gimnasia también fue un elemento principal de estos colegios religiosos. La formación integral tenía como base una buena salud física y psicológica. Esa idea llevó, por ejemplo, al Colegio el Pilar, a desarrollar un trabajo conjunto entre la Gimnasia, la Inspección Médica y el Laboratorio de Psicología aplicada. Todos estos servicios representados en la colección fotográfica de las memorias constituyen un elemento más del servicio especial que ofrecían y que los distinguía.

Otro elemento del ideario educativo que se observa como representativo de estas escuelas, es el protagonismo de las actividades que contribuyen a la formación estética del individuo. En la mayor parte de las memorias analizadas se observa una alusión constante al concepto de educación integral del sujeto en la que se incluye la formación estética. Aparecen numerosas fotografías en las que se plasman actividades con las que se favorece la formación del sentimiento estético de los alumnos a través del teatro, de concursos de poesía, de fotografía, de música y del canto, con sesiones de cineforum mensuales, dibujo artístico y lineal (Fotografía 22, extraída de una Memoria del Centro posiblemente realizada por un fotógrafo profesional), concursos de declamación, exposiciones escolares, revistas escolares, etc.

La activa vida cultural de estos centros -mediante excursiones y visitas culturales, conferencias sobre futuro profesional, conferencias musicales, cursillos de formación cinematográfica- les proporcionaba cauces de expresión, visibilización y distinción sociocultural. La música, por ejemplo, ocupó una parte importante de las enseñanzas del centro, ofreciendo a los estudiantes clases de arte musical, y los más aventajados estudiaban música instrumental pudiendo participar en la Orquesta Colegial. ${ }^{49}$

Para legitimar una identificación de los estudiantes con su Colegio y, por ende, un reconocimiento social mayor, la creación de asociaciones de antiguos alumnos y clubes sociales, sería otro elemento diferenciador. El Colegio se rodeaba de familias de la élite social con las que nunca perdía el contacto, convirtiéndose en un lugar que garantizaba el encuentro y relación entre las familias burguesas madrileñas. Este aspecto consideramos que es un signo de identidad elitista que comparten este tipo de

\footnotetext{
${ }^{49}$ Calvo, El Colegio de Nuestra Señora de las Maravillas. Crónica de cien años. 1892-1992, 62.
} 

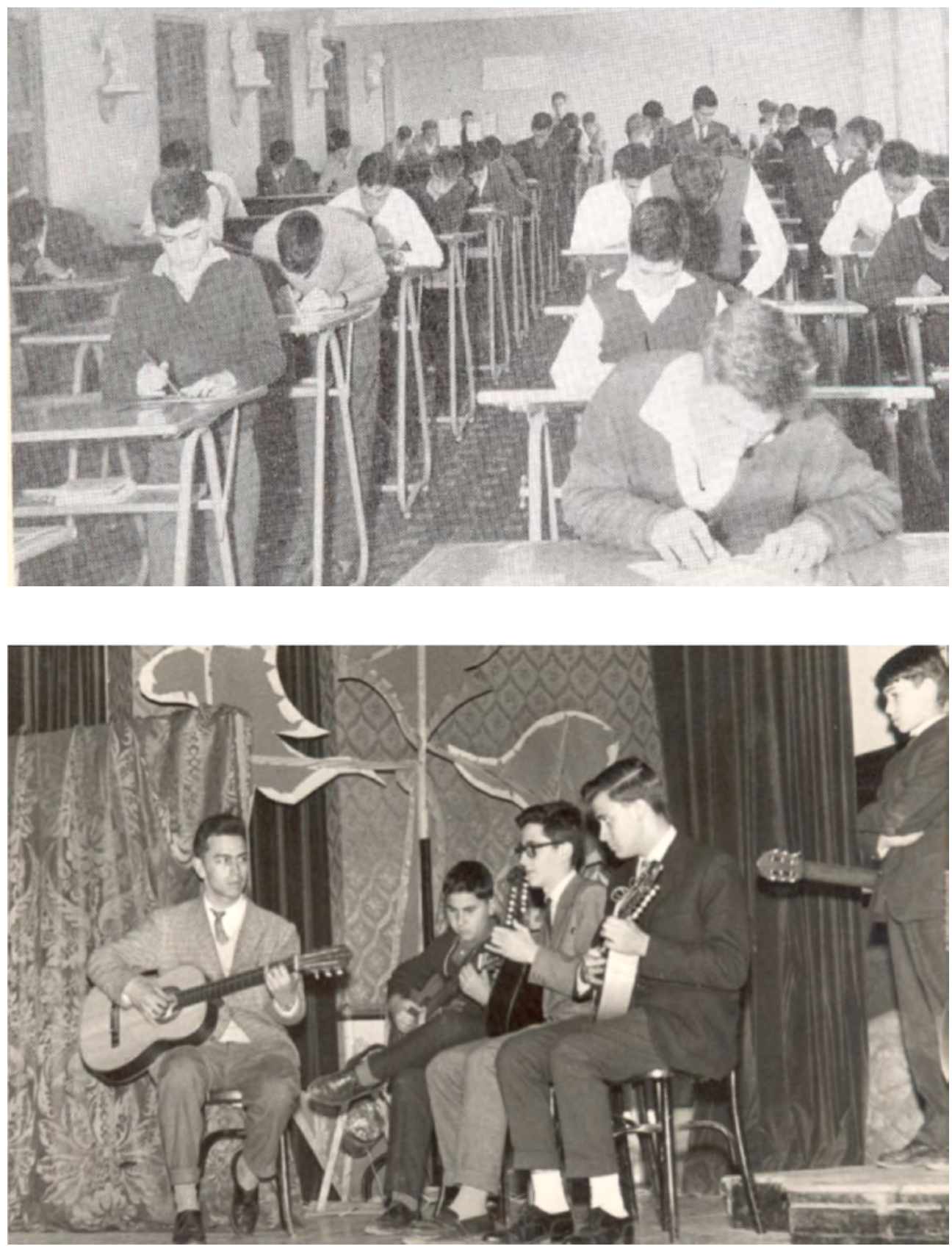

Fotografías 22 y 23. Izquierda: Alumnado en clase de educación artística del Colegio MaravillasLa Salle, Madrid, 1964 (FRM 884). Derecha: Actuación musical de un grupo de alumnos del Colegio El Pilar, Madrid, 1962 (FRM 882) 
colegios. ${ }^{50}$ Las diferentes congregaciones religiosas fomentaron la creación de estas asociaciones siguiendo el espíritu familiar y paternal que profesaban. Los objetivos se dirigían a fomentar lo sentimental, lo benéfico, a cultivar el amor por el estudio y, por último, a proteger la obra educativa. En cuanto a la primera, lo que se pretendía era revivir el ambiente colegial y reafirmar los lazos de amistad y camaradería entre los alumnos de diferentes promociones. En cuanto a la benéfica, en concreto en el Colegio El Pilar, durante los años cincuenta destacan las actividades sociales desarrolladas como respuesta a las necesidades de la población madrileña situada en barrios como Ventas, La Elipa o Carabanchel. También promovió la obra social denominada CEO (Centro de Enseñanza Obrera) que, vinculada a las labores catequístico-benéficas del centro, se dedicaba a dar clases nocturnas para obreros a cargo de alumnos de los últimos cursos y estudiantes egresados. Toda esta vocación de servicio entronca con la formación social de estudiantes que pasaron por las escuelas religiosas. Las imágenes que aparecen en las memorias muestran una continuidad con la concepción cristiana de ayuda al prójimo, haciendo hincapié en las obras benéficas, llamando a la responsabilidad social de estos estudiantes de la clase acomodada. También a través de su colaboración con premios y becas concedidas a los alumnos más brillantes del colegio y becas destinadas a los niños necesitados, creando patronatos de escuelas gratuitas, entre otras acciones, trataban de cubrir el principio cristiano de ayuda al prójimo. Las familias también crearon una Asociación de Padres durante los años cuarenta al entender que así se completaba la obra de la familia, la calle y el colegio. ${ }^{51}$

Pero no hay que olvidar que, como señala Hobsbawm, con la creación de asociaciones de ex-alumnos en centros privados, que tuvo su origen en Gran Bretaña a finales del siglo diecinueve, estas llegaron a tener un poder de influencia muy grande a nivel social y económico. Afirma que estas «redes informales creadas por la escuela y la universidad, reforzadas por la continuidad familiar, la sociabilidad empresarial y los clubes, eran más eficaces que las asociaciones formales.» ${ }^{52}$

\footnotetext{
${ }^{50}$ Yetano, La enseñanza religiosa en la España de la Restauración, 128.

${ }^{51}$ AA. VV., El Pilar, cien años de historia, 123.

${ }^{52}$ Eric Hobsbawm, «La fabricación en serie de tradiciones: Europa, 1870-1914», en La invención de la tradición, eds. Eric Hobsbawm y Terence Ranger (Barcelona: Crítica, 2002), 307.
} 


\section{LA REPRESENTACIÓN DE LA ENSEÑANZA PRIVADA: METODOLOGÍA COMPETITIVA E INDIVIDUALIZADA}

En la mayor parte de los colegios privados referenciados en las memorias de prácticas, resulta difícil ver representada la enseñanza que se practicaba en las aulas. En general, el estilo de aula que muestran entronca con las tradiciones docentes que se asumen como eficaces. En su mayoría, son imágenes de una acción escolar cotidiana estática e inmóvil al representar un aula tradicional simbolizando un modelo de enseñanza magistrocéntrico, en el que el docente es el actor principal mientras que el alumno escucha, asume y es evaluado, donde la pizarra representa un papel simbólico como espacio de producción de saberes. ${ }^{53}$ En general, el modelo de enseñanza católico va a identificarse con un modelo autoritario, en consonancia con la organización eclesial a la que pertenecía. ${ }^{54}$ Sin embargo, en los centros analizados se han seleccionado dos ejemplos donde se muestran propuestas metodológicas diferentes al sistema tradicional, como pueden ser la enseñanza competitiva y la individualizada.

En la siguiente fotografía ejemplificamos el modelo de enseñanza competitiva y de emulación que emplearon los centros privados. En concreto, en esta imagen, correspondiente al Colegio Maravillas-La Salle, se observa una redefinición del uso del espacio del aula que rompe con el sistema de enseñanza tradicional. En la composición de la imagen (fotografía 24) se modifica la identidad de los protagonistas principales, personificada en los estudiantes y no en el profesor. Por otro lado, el espacio de la pizarra está bajo dominio de los estudiantes, mientras que el docente aparece en un segundo plano de la actividad escolar, mostrando al mismo tiempo una cercanía nada visible en la imagen tradicional de aula. La actividad escolar que aparece nos acerca a una metodología de aprendizaje más activo, más cercana al paidocentrismo. Como se puede observar en una de las imágenes, a través de un concurso o competición los niños aprenden matemáticas de una forma más lúdica y más cercana a sus intereses. Al ser un colegio de varones, el docente atrae la atención y motivación de sus alumnos a través de un tema muy recurrente para los niños como es el fútbol.

\footnotetext{
${ }^{53}$ Hobsbawm, «La fabricación en serie de tradiciones: Europa, 1870-1914», 307.

${ }^{54}$ Yetano, La enseñanza religiosa en la España de la Restauración, 107.
} 

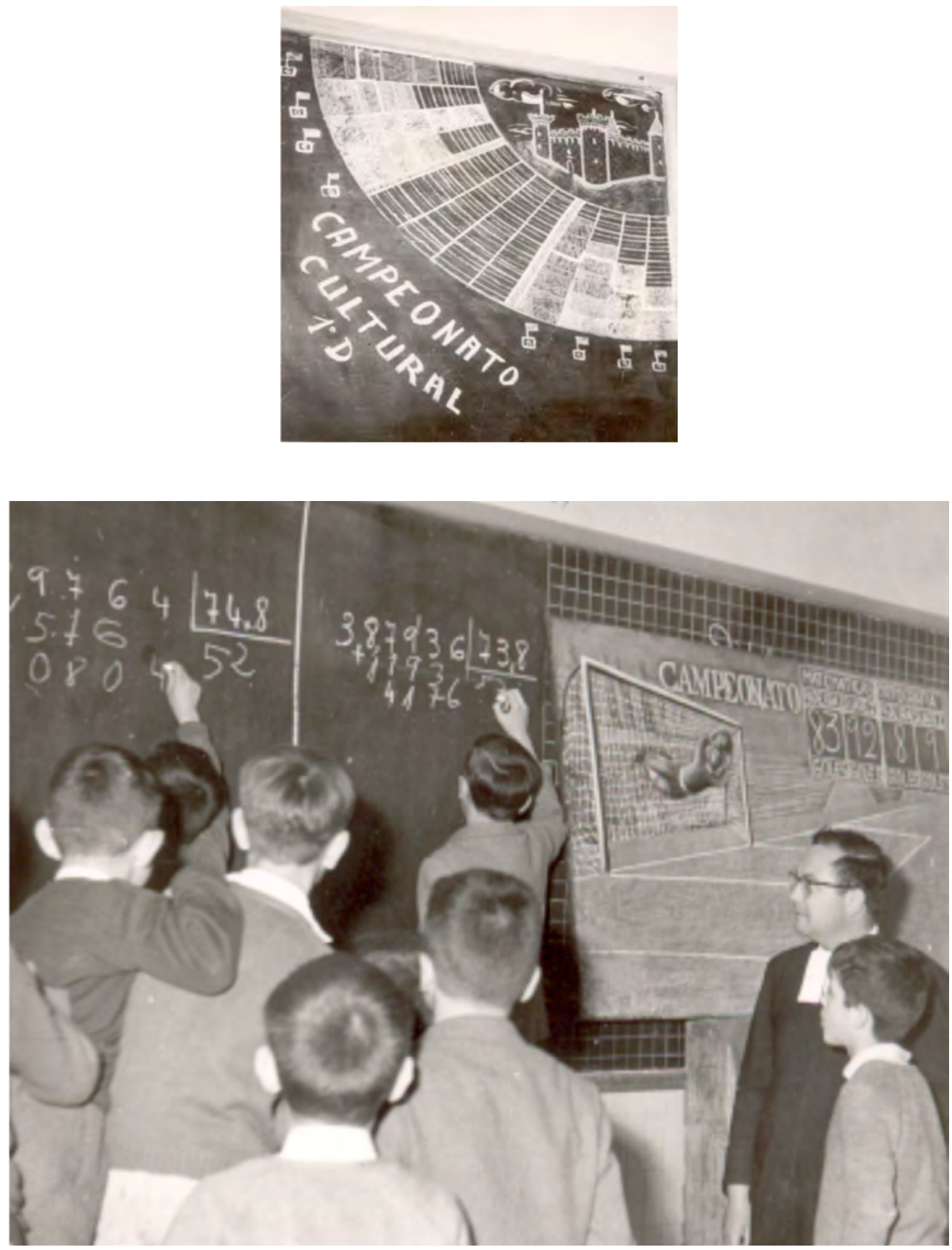

Fotografías 24 y 25. Los habituales campeonatos culturales del Colegio Maravillas-La Salle, Madrid, 1964 (FRM 884). Ambas imágenes fueron realizadas por el autor de la memoria de prácticas. 
Fue una constante de la vida escolar del Maravillas el empleo de los campeonatos culturales para el aprendizaje de los contenidos de una forma lúdica y divertida, como observa el autor de la memoria (Fotografía 25). Con este tipo de actividades además se lograba relacionar los aprendizajes de todas las materias. El autor de la memoria explicaba cómo era el procedimiento seguido por el profesor:

Se propone a los escolares que se apoderen del castillo y de cuantos misteriosos tesoros encierra. [...]. La clase se divide en cuatro grupos con otros tantos generales o jefes de sección, previamente escogidos por ellos. Cada lección sabida puede ser un paso en el áspero camino que separa del castillo. Y tanto las matemáticas como la Historia, la gramática como el mismo dibujo, y todo el conjunto de asignaturas, que integran el Programa del curso, van cayendo en la lucha cotidiana, en donde las verdaderas víctimas son las numerosas lecciones, trilladas mil veces por las militares botas de unos chicos entusiasmados en la ardua tarea del repaso y asimilación de las distintas materias del programa. ${ }^{55}$

Otro ejemplo claro de este tipo de enseñanza basada en la emulación era el empleado en el Colegio el Pilar en el que mediante un sistema de puntos se iba evaluando el trabajo de los alumnos de cero a cien. Esto se completaba con un volante de notas que se diferencian por colores (rojo, azul, verde, marrón y negro) según el rendimiento del alumno. La nota negra, o censura, obligaba al alumno a trabajar en el colegio el domingo por la mañana. ${ }^{56}$

En contraposición a la enseñanza competitiva de los centros masculinos, coexiste el modelo de enseñanza personalizada promovido por el Instituto Véritas para la educación de las mujeres. En la fotografía 26 — realizada por la estudiante - se puede apreciar, un elemento diferenciador respecto a la coreografía escolar de otros centros privados, como la organización del aula en mesas individuales, alternando disposicio-

\footnotetext{
55 Toribio Gutiérrez Alonso, Labor educativa en un centro de segunda enseñanza. Colegio Nuestra Señora de las Maravillas (FRM 681, 1964).

${ }^{56}$ Pedro González Blasco, Pedro y Juan de Isasa, «Los marianistas en Madrid (1907-1921)», en El Pilar, cien años de historia, 1907-2007, ed. AA. VV. (Madrid: Colegio Nuestra Señora del Pilar, 2007), 29.
} 
nes grupales. En esta fotografía se puede observar de forma simultánea la aplicación del sistema de enseñanza individualizada con metodologías cooperativas o de trabajo en grupo, que supriman la rivalidad y la competición y favorezcan el enriquecimiento mutuo y la colaboración, distanciándose del modelo educativo competitivo seguido por otros centros privados. De una forma gráfica lo explica una teresiana al hablar de esta experiencia: «durante el tiempo de trabajo personal, el silencio, por ejemplo, no es una observancia: cada alumno puede comunicarse con sus compañeros para ayudarles o pedir ayuda e igualmente con los profesores». ${ }^{57}$

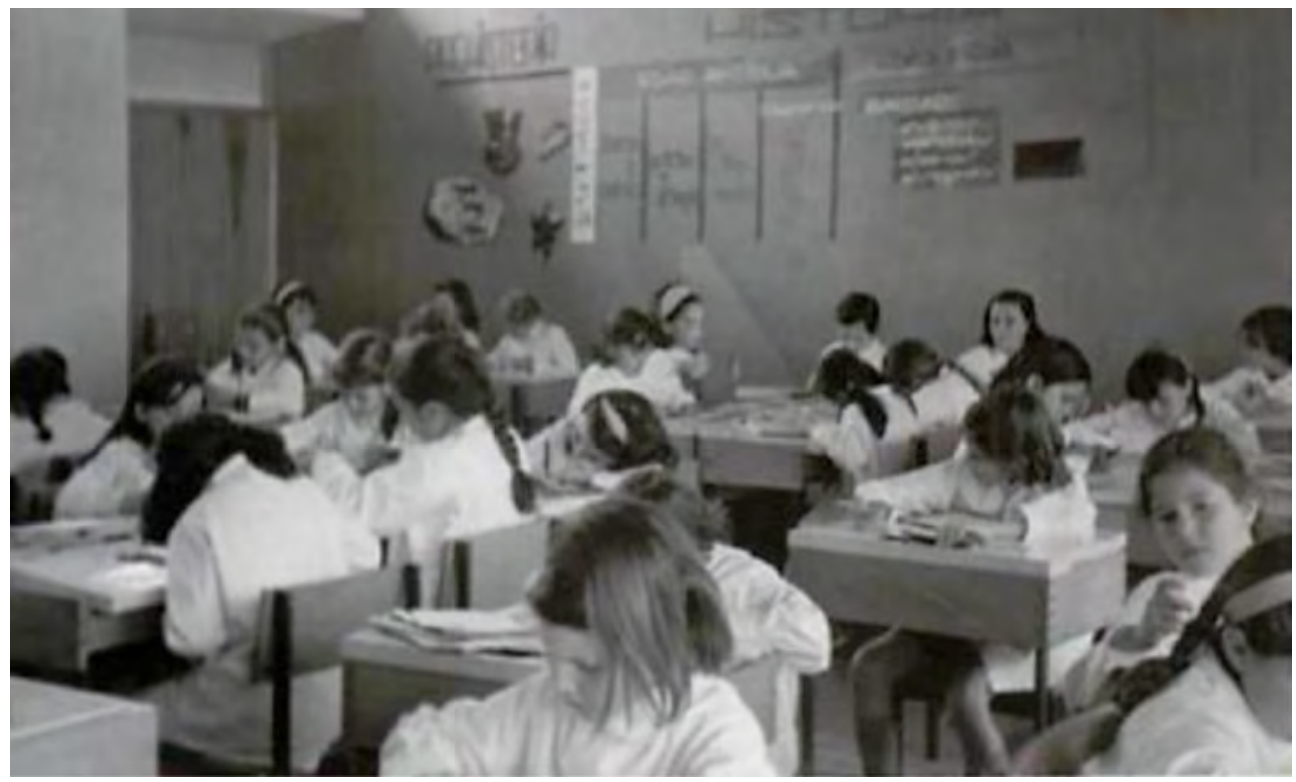

Fotografía 26. Aula del Instituto Véritas, 1964 (FRM 13)

En esta fotografía también se aprecia la utilización del mural como recurso metodológico. A través de la técnica del mural se expone de forma atractiva una información relevante sobre un tema de estudio como, en este caso, una lección de historia. De forma complementaria, se puede comprobar en el texto escrito de una de las memorias la per-

\footnotetext{
${ }^{57}$ Gutiérrez Ruiz, «El maestro de la experiencia Somosaguas», 186.
} 
tinencia de que una de las paredes de las aulas del centro sea revestida de corcho, con el fin de que permitan la exposición de los trabajos de las alumnas y la realización de murales como estrategia expositiva y pedagógica.

Las autoras de las memorias señalan que al inicio de la semana se proporcionaba a las alumnas un plan de trabajo para que desarrollasen la autonomía personal, mediante la utilización de una tabla o ficha-guía que la niña iba cumplimentando con colores, a medida que realizaba las tareas semanales asignadas, desarrollando de este modo la responsabilidad, y la voluntad, etc. ${ }^{58}$ Se ponía el énfasis en adecuar el aprendizaje a los diferentes niveles de desarrollo de las estudiantes, estableciendo planes de trabajo y fichas directivas o fichas-guía que se adaptaran al ritmo de aprendizaje de cada alumna. Dichos planes y fichas se confeccionaban para orientar las actividades del alumno. La metodología puesta en marcha en el Instituto Véritas presenta influencias de la pedagogía europea más innovadora de finales del siglo XIX y principios del siglo xx procedente de autores pertenecientes al Movimiento de Escuela Nueva (Freinet, Montessori, etc.). Los testimonios recogidos confirman que los métodos personalizados del Padre Pierre Faure ${ }^{59}$ fueron inspiradores de toda la metodología desarrollada en el centro. Grupos de maestras del Véritas viajaron a Francia para realizar cursos de formación con el propio padre Faure, que había desarrollado un sistema de metodología activa y enseñanza personalizada basado en los planes de trabajo. En palabras de Emilia Domínguez,

en julio de 1964 un grupo de profesoras fuimos a Limoges y trabajamos en una escuela de este pedagogo, escuchamos sus orien-

\footnotetext{
${ }^{58}$ Domínguez, Estudio general del Instituto Véritas y especial sobre la enseñanza primaria del referido centro, 55.Y Maestro, Estudio general sobre el Instituto Véritas y su enseñanza individualizada en los cursos $1^{\circ}, 2^{\circ}$ y $3^{\circ}$ de primaria, 30 y siguientes. En ambas memorias se incluyen ejemplos de diversos planes de trabajo adaptados a diversos grados (mensuales, quincenales y semanales), como una muestra que corrobora la metodología utilizada.

${ }^{59}$ Pierre Faure, un referente en la formación de maestros en Francia, destaca por crear en 1956 el Centre de Formation Pédagogique pour l'Enseigment Spécialisé en el Instituto Católico de Paris, así como la Association Internationale pour la Recherche et l'Animation Pédagogique en 1971. Su gran aportación conjuga las orientaciones individualistas (Plan Dalton Winnetka) y socializantes (Cousinet, Kerschenteiner, Freinet, Montessori, etc.) teniendo como base una concepción antropológica de signo cristiano. Nieves Pereira, Educación personalizada. Un proyecto pedagógico en Pierre Faure (Madrid; Narcea, 1976), 36.
} 
taciones y enseñanzas de manera práctica, elaboramos programaciones y los elementos curriculares anuales, mensuales, semanales bajo su orientación. Leímos todos los libros que estaban en francés y posteriormente se tradujo alguno al español. ${ }^{60}$

Para desarrollar la enseñanza individualizada el Padre Faure se basó en la pedagogía de Robert Dottrens, profesor del Instituto de Ciencias de la Educación en Ginebra e inspirador de las fichas de trabajo. Defendía la idea de que sólo a través de la enseñanza individualizada se podían tener en cuenta las diferencias de los estudiantes de una misma clase, "en un mismo individuo, su ritmo de trabajo y las variaciones de éste, sus reacciones afectivas, su fatigabilidad y todos los factores personales que intervienen en su actividad y en su comportamiento escolar». ${ }^{61}$

Esta metodología experimental inspiradora de la reforma educativa de 1970, tenía como principios pedagógicos

la individualización; el desarrollo por el respeto a la singularidad y al ritmo personal; el respeto a la libertad; la participación por la actividad en la educación y el aprendizaje; la preocupación por una formación equilibrada y armónica; la apertura por el clima de convivencia y por la ampliación de las situaciones de aprendizaje. ${ }^{62}$

Fueron años en los que se produjo una apertura y una demanda de renovación pedagógica desde diferentes asociaciones y grupos de profesorado. Se organizaron escuelas de verano para renovar la formación de los docentes de todos los niveles educativos. La IT también participó de esta renovación, formando parte de este plantel docente la profesora Ángeles Galino, que tuvo un gran protagonismo en el Ministerio de Educación, ocupando cargos como Directora General de Enseñanza Media y de Ordenación Académica. Participó en la reforma de la Ley General de Educación de 1970 y con estas palabras señala algunas de las razones de

\footnotetext{
${ }^{60}$ Entrevista a Emilia Domínguez Rodríguez.

${ }^{61}$ Robert Dottrens, La enseñanza individualizada (Buenos Aires: Biblioteca de cultura pedagógica, 1951), 13.

${ }^{62}$ Gutiérrez Ruiz, «El maestro de la experiencia Somosaguas», pp. 182-183.
} 
estos cambios: «Se trataba de un cambio que venía exigido por diferentes razones, entre otras, el crecimiento económico de la década de los sesenta, por la participación española en organismos internacionales como la OIT, la UNESCO, el Consejo de Europa, etc».63

En definitiva, a través del relato de algunos estudiantes de Pedagogía se confirma que durante los años cincuenta y sesenta hubo una continuidad de las pedagogías más renovadoras de finales del siglo xIx y principios del siglo $\mathrm{xx}$, a las que se les dio un sentido cristiano. Las innovaciones metodológicas de ciertos colegios religiosos estudiados van a conectar con la pedagogía más moderna a pesar de desarrollarse en los años de la dictadura franquista. Si bien pensamos que hasta finales de los años cincuenta el control del Estado fue mayor, los centros privados siempre tuvieron más libertad para poder emprender sus enseñanzas. La aplicación de corrientes pedagógicas modernas — autores como Freinet, Montessori, o metodologías como las del Plan Dalton y el método Cousinet, entre muchas otras-, que fueron objeto de depuración para muchos docentes en los primeros años de la dictadura franquista, no llegaron a desaparecer del todo en los escenarios escolares privados dependientes de instituciones religiosas. Por tanto, la Iglesia tuvo legitimidad educativa para introducir innovaciones y metodologías pedagógicas siempre que estuvieran impregnadas de un sentido religioso, disfrutando de mayor libertad que los centros públicos, sometidos a un control político y religioso escrupuloso.

\section{CONCLUSIONES}

Los usos de las imágenes como fuente historiográfica nos han permitido asomarnos a las representaciones de las señas de identidad de cuatro colegios religiosos de Madrid durante el franquismo, tres de ellos destinados a la educación de varones y uno a la formación de las mujeres. Las fotografías analizadas en este trabajo nos han aproximado a dos discursos. Uno, el elaborado por las propias congregaciones religiosas con un fin claro de marketing escolar, pues las imágenes publicadas tomadas por profesionales captan los elementos más identitarios de la

\footnotetext{
${ }^{63}$ Julio Ruiz Berrio, Julio y Consuelo Flecha García, «Conversación con... Ángeles Galino Carrillo, Historiadora de la Educación», Historia de la Educación 26 (2007): 533.
} 
institución a modo de «marca» del colegio. Este discurso propagandístico se circunscribe a varios elementos. Primero, al emplazamiento de los edificios, como lugares de distinción, monumentales, modernos, dotados de toda clase de infraestructuras y recursos con el fin de hacer atractiva la oferta educativa a las clases acomodadas. Coexistieron varios modelos arquitectónicos, en función de la antigüedad del centro. En la década de los años sesenta se construyeron edificios escolares con un estilo vanguardista que rompía con los estilos decimonónicos, y se realizó un uso desmesurado de la imagen de modernidad basada en una innovadora concepción social de una escuela nutrida de las modernas corrientes psicopedagógicas. Otro de los pilares básicos de los colegios religiosos, empleado en la publicidad de los centros, se vincula a la representación de la religiosidad, a través de la posición espacial que protagonizaron las capillas e iglesias en algunos de los edificios escolares. En este aspecto, convivieron dos orientaciones de vida religiosa: una promovía la participación colectiva y pública de los alumnos en los actos de culto, y otra el recogimiento intimista y privado de la oración. Por último, el discurso propagandístico también potenció la visibilización de los recursos materiales educativos, las actividades deportivas, artísticas y socio-benéficas.

Por otro lado, el segundo discurso se deriva de las fotografías que los estudiantes realizaron con el fin de reflejar los aspectos más representativos de una enseñanza con la que se identificaban en muchos casos por ser docentes de las propias instituciones. Se trató de dar más visibilidad a las innovaciones educativas; las imágenes desvelan situaciones de aprendizaje innovadoras difíciles de observar con otro tipo de fuentes, como pueden ser la enseñanza competitiva y el ensayo educativo renovador del sistema de enseñanza personalizada, inspirador de la reforma educativa de 1970.

En definitiva, la fotografía es una herramienta de comunicación que presenta unas condiciones de legibilidad social al aproximarnos a la memoria social y colectiva. Al mismo tiempo, contribuyen de manera eficaz a que la historia colectivice la memoria individual. Tiene un potencial discursivo muy revelador para el análisis publicitario y, al mismo tiempo, permite visibilizar sistemas de enseñanza desarrollados por los colegios elitistas madrileños, que difícilmente se podrían evidenciar con otro tipo de fuentes. 


\section{Nota sobre las autoras}

Sara Ramos Zamora es Profesora Contratada Doctora en el Departamento de Teoría e Historia de la Educación de la Facultad de Educación de la Universidad Complutense de Madrid (UCM). Sus líneas de investigación se insertan en el ámbito de la Historia de la Educación, destacando la memoria y cultura escolar, el patrimonio histórico-educativo y género y educación. Es miembro del Grupo de Investigación Consolidado de la UCM «Historia y Presente de la Cultura Escolar. Género e identidades». Ha participado en diversos proyectos de investigación competitivos como miembro del equipo e investigadora principal, así como en Proyectos de innovación docente vinculados a la innovación docente en la enseñanza de la Historia de la Educación. Desde el 2005 es Secretaria del Museo/ Laboratorio de Historia de la Educación «Manuel Bartolomé Cossío» y actualmente es Secretaria de la Sociedad Española de Historia de la Educación (SEDHE).

Teresa Rabazas Romero es Profesora Titular de Universidad del Departamento de Teoría e Historia de la Educación de la Universidad Complutense de Madrid. Doctora en Filosofía y Ciencias de la Educación por la mencionada universidad con la obtención de Premio Extraordinario de Doctorado. Ha desarrollado como líneas principales de investigación, como autora o coautora de diferentes artículos y libros, el estudio y el análisis de los manuales como objeto y fuente de conocimiento de la cultura escolar en la España contemporánea, así como el análisis del currículo, la historia de la educación de las mujeres, análisis iconográfico de la cultura escolar y la museología de la educación. Ha colaborado en investigaciones nacionales e internacionales como miembro del equipo de investigación e Investigador principal (Proyecto MANES, Instituto de la Mujer I+D, CICYT, etc.). Actualmente, dirige el grupo de investigación de la Universidad Complutense de Madrid, que lleva por título «Historia y presente de la cultura escolar. Género e Identidades» (CCGO7-UCM/ HUM-2280). Es directora del Museo/Laboratorio de Historia de la Educación «Manuel Bartolomé Cossío» de la Facultad de Educación (UCM) y Directora de la Colección Pedagógico Textil Complutense. También forma parte de la Junta Directiva, como Tesorera, de la Sociedad para el Patrimonio Histórico-Educativo (SEPHE). 
Carmen Colmenar Orzaes. Profesora Titular del actual Departamento de Estudios educativos de la Facultad de Educación de la UCM. Sus líneas de investigación se han centrado en la historia de la infancia y de la educación infantil, en la historia de la educación de las mujeres y en la museología y museografía de la educación. Ha participado en diversos proyectos de investigación desde 1992 hasta el momento actual, formando parte del grupo de investigación de la UCM, «Historia y presente de la cultura escolar. Género e identidades». Es miembro de diversas sociedades científicas y ha participado en múltiples congresos. Entre sus publicaciones, hay que mencionar: «La protección a la primera infancia en España en el primer tercio del siglo xx», en la revista History of Education \& Children's Literature, 1, 2006; «La institucionalización de la maternología en España durante la Segunda República y el Franquismo», en la revista Historia de la Educación. Revista interuniversitaria, $\mathrm{n}^{\circ}$ 28, 2009; «El Museo de Historia de la Educación "Manuel Bartolomé Cossío"», en Ruiz Berrio, J. (Ed.). El patrimonio histórico-educativo. Su conservación e historia. Madrid, Biblioteca Nueva. 2010, pp. 339-360; «La introducción de los Jardines de Infancia en España. Aportaciones de Pedro de Alcántara García y Eugenio Bartolomé Mingo», en Sanchidrián, C. y Ruiz Berrio, J. (coords.). Historia y perspectiva actual de la educación infantil. Barcelona, Grao. 2010; y «Mujeres rurales y capacitación profesional en el franquismo a través de la prensa femenina (1939-1959)», en Educació i Historia: Revista d'Història de l'Educació, 24 (2014), pp. 135-171.

\section{REFERENCIAS}

AA.VV. El Pilar, cien años de historia, 1907-2007. Madrid: Colegio Nuestra Señora del Pilar, 2007.

Barceló, Gabriel, Francesca Comas y Bernat SuREda. «Abriendo la caja negra: la escuela pública española de postguerra». Revista de Educación 371 (2015): 61-82.

Bardin, Laurence. Análisis de contenido. Madrid: Akal, 2002.

BeLloti, Elisa. "Qualitative Methods and Visualizations in the Study of Friendship Networks». Sociological Research Online 21, no. 2 (2016): 2. http://www. socresonline.org.uk/21/2/2.html.

Bourdieu, Pierre. «Deporte y clase social». En Materiales de sociología del deporte, editado por José Ignacio Barbero, 57-82. Madrid: La Piqueta, 1993. 
Burke, Catherine e Ian Grosvenor. «The progressive image in the history of education: stories of two schools». Visual Studies 22, no. 2 (2007):155-168.

Colmenar Orzaes, Carmen. «El Museo de historia de la Educación Manuel Bartolomé Cossío». En El patrimonio histórico-educativo. Su conservación y estudio, editado por Julio Ruiz, 339-361. Madrid: Biblioteca Nueva, 2010.

Comas, Francesca, Sara González, Xavier Motilla y Bernat Sureda. Imatges de l'escola, imatge de l'educació. Palma: Universidad de las Islas Balears, 2014. Actas de les xxi Jornades d'Història de l'Educació, celebradas entre el 26 al 28 de noviembre de 2014.

Comas RuBI, Francesa. «Localització, anàlisi i utilització de la fotografía com a font per a la historia de lèducació els projectes desenvolupats en el Grup d'Estudis d'Història de l'Educació de la UIB». En Investigar la Història de l'Educació am imatges, coordinado por Eulàlia Collelldemont, 53-64. Vic: Eumogràfic - MUVIP, 2014.

Comas, Francesca, Xavier Motilla y Bernat Sureda. Fotografia e història de l'educació. Iconografia de la modernització educativa. Palma: Leonard Muntaner, 2012.

Dávila Balsera, Paulí. «Las órdenes y congregaciones religiosas francesas y su impacto sobre la educación en España. Siglos XIX y XX». En Francia en la educación de la España Contemporánea (1808-2008), editado por José María Hernández, 101-159. Salamanca: Ediciones Universidad Salamanca, 2011.

Dávila, Paulí y Luis María NaYA. «La enseñanza privada religiosa en España: instituciones, políticas e identidades». En Laicidade, Religioes e Educaçao na Europa do Sul no Século XX, editado por Joaquím Pintassilgo, 367-392. Lisboa: Instituto de Eduaçao da Universidade de Lisboa, 2013.

Dávila, Paulí, Luis María NAYA e Iñaki ZaBALETA. «Internados religiosos: marketing del espacio a través de las Memorias escolares en España durante el primer tercio del siglo xx». En Espacios y patrimonio histórico-educativo. VII Jornadas científicas de la SEPHE y V Simposio Iberoamericano, coordinado por Paulí Dávila y Luis María Naya, 183-208. Donostia-San Sebastián: Universidad del País Vasco, 2016.

- «Memory and Yearbooks: An Analysis of Their Structure and Evolution in Religious Schools in 20th Century Spain». En School Memories New Trends in the History of Education, editado por Cristina Yanes, Juri Meda y Antonio Viñao, 65-79. Suiza: Springer, 2017.

Dávila, Paulí, Luis María Naya e Hilario Murua. Bajo el signo de la educación. 100 años de la Salle en Gipuzkoa. Bilbao: Hermanos de las Escuelas Cristianas, 2009.

- «Prácticas y actividades religiosas en los colegios privados del País Vasco durante el siglo xx». Historia y Memoria de la Educación 4 (2016): 141-175. 
Delaunay, Jean Marie. «Exilio o refugio en España (veinticinco años después)». Anuario de la Iglesia 16 (2005): 153-164.

Depaepe, Marc y Bregt Henkens. "The Challenge of the Visual in the History of Education». Paedagogica Historica. International Journal of the History of Education 36, no.1 (2000): 11-17.

DotTRens, Robert. La enseñanza individualizada. Buenos Aires: Biblioteca de cultura pedagógica, 1951.

DuRÁ GúRPIDE, Isabel. «La escuela activa en las revistas de Arquitectura». En 4. ${ }^{a}$ Jornadas Internacionales sobre investigación en arquitectura y urbanismo, coordinado por Autores Varios, 4-17. Valencia: Universidad de Valencia, 2011.

Faubell Zapata, Vicente. "Órdenes, Congregaciones y Asociaciones eclesiales masculinas dedicadas a la educación y a la enseñanza». En Historia de la acción educadora de la Iglesia en España. Tomo II. Edad Contemporánea, editado por Bernabé Bartolomé, 323-448. Madrid: Biblioteca de Autores Cristianos, 1997.

Faubell Zapata, Vicente. «Educación y órdenes y congregaciones religiosas en la España del siglo xx». Revista de Educación, no. Extraordinario (2000): 137200.

García CARBallo, Ángela. «Urbanizaciones de lujo y segregación residencial de las clases altas en Somosaguas, Pozuelo de Alarcón (Madrid)». Ería: Revista cuatrimestral de Geografía 94 (2014): 125-144.

Grosvenor, Ian. "From the «Eye of History» to "a Second Gaze»: The Visual Archive and the Marginalized in the History of Education». History of Education 36, no. 4-5 (2007): 607-622.

GutiérRez RuIz, Irene. «El maestro de la experiencia Somosaguas». Tendencias pedagógicas 14 (2009): 181-189.

- Experiencia Somosaguas. Madrid: Iter ediciones, 1970.

Hobsвawm, Eric. «La fabricación en serie de tradiciones: Europa, 1870-1914». En La invención de la tradición, editado por Eric Hobsbawm y Terence Ranger, 273-318. Barcelona: Crítica, 2002.

Isasa GonzÁlez de Ubieta, Juan de. Colegio del Pilar. 75 años (1907-1982). Abiertos a la sociedad. Madrid: Colegio el Pilar, 1982.

LóPez Martín, M. ${ }^{a}$ José. «La Academia de Santa Teresa de Málaga (1963). Una propuesta común de arquitectos y pedagogos». En Espacios y patrimonio histórico-educativo. VII Jornadas científicas de la SEPHE y V Simposio Iberoamericano, coordinado por Paulí Dávila y Luis M. Naya, 117-133. Donostia-san Sebastián: Universidad del País Vasco, 2016.

Mangan, J.A. Athleticism in the Victorian and Edwardian Public School. Lewes: Falmer Press, 1981. 
McCauley, Anne. «Francois Arago and the politics of the French Invention of Photography». En Multiple views: logan grant essays on photography. 19831989, editado por Daniel P. Jounger, 43-69. Alburquerque: University of New Mexico Press, 1991.

Martínez Navarro, Anastasio. «Un Seminario sobre fuentes históricas en el Museo de historia de la Educación de la Facultad de Educación de la Universidad Complutense». Revista Complutense de Educación 8, no. 1(1997): 305318.

Moreno, Pedro Luís y Ana Sebastián. Patrimonio y etnografía de la escuela en España y Portugal durante el siglo XX. Murcia: SEPHE y CEME, 2012.

Ostolaza Esnal, Maitane. Entre religión y modernidad: los colegios de las Congregaciones Religiosas en la construcción de la sociedad guipuzcoana contemporánea, 1876-1931. Bilbao: Universidad del País Vasco, 2000.

OstolazA, Maitane y Pere FullanA. «Escuela católica y modernización. Las nuevas congregaciones religiosas (1900-1930)». En La secularización conflictiva. España (1898-1931), editado por Julio de la Cueva y Feliciano Montero, 187213. Madrid: Biblioteca Nueva, 2007.

Pereira de Gómez, M. ${ }^{a}$ Nieves. Educación personalizada un proyecto pedagógico en Pierre Faure. Madrid: Narcea, 1976.

Peña, Agustina de la. "50 años del Instituto Véritas». Boletín informativo de la Federación Pedro Poveda de Asociaciones de Madres y Padres de Alumnos de Centros Educativos Institución Teresiana 16 (2011): 16-17.

Pozo ANDrés, M. ${ }^{a}$ del Mar del. «Imágenes e historia de la educación: construcción, reconstrucción y representación de las prácticas escolares en el aula». Historia de la Educación 25 (2006): 291-315.

Pozo, María del Mar del y Teresa RABAzAs. «Imatges fotogràfiques i cultura escolar en el franquisme: una exploració de l'arxiu etnogràfic». Educació $i$ Història. Revista d'Història del'Educació 15 (2010): 165-194.

Rosioue Navarro, Francisca. Historia de la Institución Teresiana (1911-1936). Madrid: Silex Ediciones, 2014.

Ruiz, Julio y Consuelo Flecha. «Conversación con.... Ángeles Galino Carrillo, Historiadora de la Educación». Historia de la Educación 26 (2007): 519-538.

VALLE LóPEZ, Ángela del. «Una pedagogía para la educación integral en la obra de Pedro Poveda: Desarrollo de las capacidades y actitudes físicas». Historia de la Educación 14-15 (1995-1996): 173-196.

Velasco Maillo, Honorio M. «Fotografías escolares, imágenes institucionales». En Antropología audiovisual: medios e investigación en educación, coordinado por Antonio Bautista y Honorio M. Velasco, 15-34. Madrid: Trotta, 2011. ViÑao, Antonio y María José Martínez. «Picture Postcards as a Tool for Constructing and Reconstructing Educational Memory (Spain, 19th-20th Centu- 
ries)». En School Memories New Trends in the History of Education, editado por Cristina Yanes, Juri Meda y Antonio Viñao, 29-45. Suiza: Springer, 2017. VIÑAo Frago, Antonio. "Los espacios escolares ¿cómo abordar un objeto polifacético y multiforme?». En Espacios y patrimonio histórico-educativo, coordinado por Paulí Dávila y Luis M. ${ }^{a}$ Naya, 25-59. San Sebastián: Erein, 2016. Yetano Sánchez De Muniaín, Ana. La enseñanza religiosa en la España de la Restauración (1900-1920). Barcelona: Anthropos, 1987. 